\title{
Unusual 4-arsonoanilinium cationic species in the hydrochloride salt of (4-aminophenyl)arsonic acid and formed in the reaction of the acid with copper(II) sulfate, copper(II) chloride and cadmium chloride
}

\section{Graham Smith and Urs D. Wermuth}

Acta Cryst. (2017). C73, 325-330

\section{H IUCr Journals CRYSTALLOGRAPHY JOURNALS ONLINE \\ Copyright (C) International Union of Crystallography \\ Author(s) of this paper may load this reprint on their own web site or institutional repository provided that this cover page is retained. Republication of this article or its storage in electronic databases other than as specified above is not permitted without prior permission in writing from the IUCr. \\ For further information see http://journals.iucr.org/services/authorrights.html}


STRUCTURAL

CHEMISTRY

ISSN 2053-2296

Received 12 February 2017

Accepted 25 February 2017

Edited by A. R. Kennedy, University of Strathclyde, Scotland

Keywords: p-arsanilic acid; 4-arsonoanilinium; coordination polymers; copper(II) chloride salts; cadmium chloride salts; hydrogen bonding; crystal structure.

CCDC references: $1534722 ; 1534721$; $1534720 ; 1534719$

Supporting information: this article has supporting information at journals.iucr.org/C

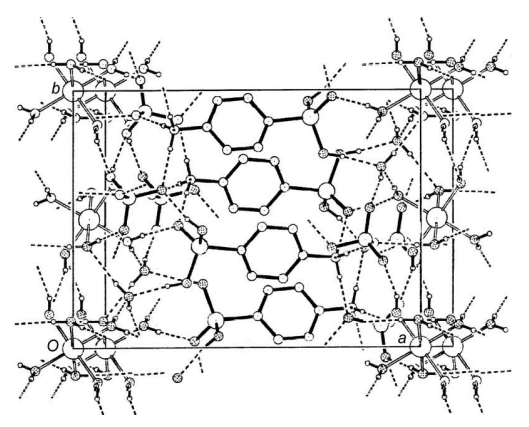

(C) 2017 International Union of Crystallography

\section{Unusual 4-arsonoanilinium cationic species in the hydrochloride salt of (4-aminophenyl)arsonic acid and formed in the reaction of the acid with copper(II) sulfate, copper(II) chloride and cadmium chloride}

\author{
Graham Smith $^{\mathrm{a} *}$ and Urs D. Wermuth ${ }^{\mathrm{b}}$
}

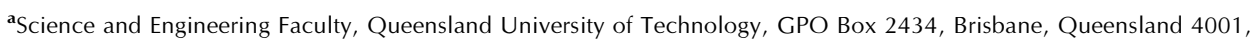
Australia, and ${ }^{\mathbf{b}}$ School of Natural Sciences, Griffith University, Nathan, Queensland 4111 , Australia. ${ }^{*}$ Correspondence e-mail: gsmith@bigpond.com

Structures having the unusual protonated 4-arsonoanilinium species, namely in the hydrochloride salt, $\mathrm{C}_{6} \mathrm{H}_{9} \mathrm{AsNO}_{3}{ }^{+} \cdot \mathrm{Cl}^{-}$, (I), and the complex salts formed from the reaction of (4-aminophenyl)arsonic acid ( $p$-arsanilic acid) with copper(II) sulfate, i.e. hexaaquacopper(II) bis(4-arsonoanilinium) disulfate dihydrate, $\left(\mathrm{C}_{6} \mathrm{H}_{9} \mathrm{AsNO}_{3}\right)_{2}\left[\mathrm{Cu}\left(\mathrm{H}_{2} \mathrm{O}\right)_{6}\right]\left(\mathrm{SO}_{4}\right)_{2} \cdot 2 \mathrm{H}_{2} \mathrm{O}$, (II), with copper(II) chloride, i.e. poly[bis(4-arsonoanilinium) [tetra- $\mu$-chlorido-cuprate(II)]], $\left\{\left(\mathrm{C}_{6} \mathrm{H}_{9} \mathrm{AsNO}_{3}\right)_{2}-\right.$ $\left.\left[\mathrm{CuCl}_{4}\right]\right\}_{n}$, (III), and with cadmium chloride, i.e. poly[bis(4-arsonoanilinium) [tetra$\mu$-chlorido-cadmate(II)]], $\left\{\left(\mathrm{C}_{6} \mathrm{H}_{9} \mathrm{AsNO}_{3}\right)_{2}\left[\mathrm{CdCl}_{4}\right]\right\}_{n},(\mathrm{IV})$, have been determined. In (II), the two 4-arsonoanilinium cations are accompanied by $\left[\mathrm{Cu}\left(\mathrm{H}_{2} \mathrm{O}\right)_{6}\right]^{2+}$ cations with sulfate anions. In the isotypic complex salts (III) and (IV), they act as counter-cations to the $\left\{\left[\mathrm{CuCl}_{4}\right]^{2-}\right\}_{n}$ or $\left\{\left[\mathrm{CdCl}_{4}\right]^{2-}\right\}_{n}$ anionic polymer sheets, respectively. In (II), the $\left[\mathrm{Cu}\left(\mathrm{H}_{2} \mathrm{O}\right)_{6}\right]^{2+}$ ion sits on a crystallographic centre of symmetry and displays a slightly distorted octahedral coordination geometry. The asymmetric unit for (II) contains, in addition to half the $\left[\mathrm{Cu}\left(\mathrm{H}_{2} \mathrm{O}\right)_{6}\right]^{2+}$ ion, one 4-arsonoanilinium cation, a sulfate dianion and a solvent water molecule. Extensive $\mathrm{O}-\mathrm{H} \cdots \mathrm{O}$ and $\mathrm{N}-\mathrm{H} \cdots \mathrm{O}$ hydrogen bonds link all the species, giving an overall three-dimensional structure. In (III), four of the chloride ligands are related by inversion $[\mathrm{Cu}-\mathrm{Cl}=2.2826$ (8) and 2.2990 (9) $\AA$, with the other two sites of the tetragonally distorted octahedral $\mathrm{CuCl}_{6}$ unit occupied by symmetrygenerated $\mathrm{Cl}$-atom donors $[\mathrm{Cu}-\mathrm{Cl}=2.9833$ (9) $\AA$ ], forming a two-dimensional coordination polymer network substructure lying parallel to (001). In the crystal, the polymer layers are linked across [001] by a number of bridging hydrogen bonds involving $\mathrm{N}-\mathrm{H} \cdots \mathrm{Cl}$ interactions from head-to-head-linked As-O$\mathrm{H}$... $\mathrm{O}$ 4-arsonoanilinium cations. A three-dimensional network structure is formed. $\mathrm{Cd}^{\mathrm{II}}$ compound (IV) is isotypic with $\mathrm{Cu}^{\mathrm{II}}$ complex (III), but with the central $\mathrm{CdCl}_{6}$ complex repeat unit having a more regular $M-\mathrm{Cl}$ bond-length range [2.5232 (12)-2.6931 (10) $\mathrm{A}]$ compared to that in (III). This series of compounds represents the first reported crystal structures having the protonated 4-arsonoanilinium species.

\section{Introduction}

The chemistry of (4-aminophenyl)arsonic acid $[p$-arsanilic acid $p$ - $\left.\left(\mathrm{NH}_{2}\right) \mathrm{C}_{6} \mathrm{H}_{4}\left(\mathrm{AsO}_{3} \mathrm{H}_{2}\right), \mathrm{PARSH}_{2}\right]$ was first described by Ehrlich \& Bertheim (1907) and the compound still has veterinary applications as an antihelminth (Steverding, 2010). The crystal structure of this acid has confirmed the presence of an $\mathrm{NH}_{3}{ }^{+}-\mathrm{AsO}_{2} \mathrm{HO}^{-}$zwitterion (Shimada, 1961; Nuttall \& Hunter, 1996), which has also been found in a number of metal complex structures involving this acid, for example, in the complexes $\left\{\left[\mathrm{CdCl}_{2}\left(4-\mathrm{NH}_{3} \mathrm{C}_{6} \mathrm{H}_{4} \mathrm{AsO}_{3} \mathrm{H}\right)\right] \cdot 2 \mathrm{H}_{2} \mathrm{O}\right\}_{n}$ and $[\mathrm{Pb}-$ 
Table 1

Experimental details.

(I)
(II)
(III)

$\left(\mathrm{C}_{6} \mathrm{H}_{9} \mathrm{AsNO}_{3}\right)_{2}\left[\mathrm{CuCl}_{4}\right]$

641.47

Orthorhombic, $\mathrm{Pbca}$

200

7.6315 (4), 7.1244 (4),

$38.0925(15)$

90, 90, 90

2071.08 (18)

Mo $K \alpha$

4.77

$0.25 \times 0.25 \times 0.04$
Oxford Diffraction

Gemini-S CCD-

detector

Multi-scan (CrysAlis

PRO; Rigaku OD,

2015)

$0.544,0.980$

$6065,2028,1715$

0.032

0.617

$0.034,0.090,1.13$

2028

139

5

$\mathrm{H}$ atoms treated by a mixture of independent and constrained refinement

$0.42,-0.57$
(IV)

$\left(\mathrm{C}_{6} \mathrm{H}_{9} \mathrm{AsNO}_{3}\right)_{2}\left[\mathrm{CdCl}_{4}\right]$

690.32

Orthorhombic, $\mathrm{Pbca}$

200

7.5525 (4), 7.2578 (3), $38.5872(17)$

90, 90, 90

2115.14 (17)

Mo $K \alpha$

4.67

$0.41 \times 0.25 \times 0.10$

Oxford Diffraction

Gemini-S CCDdetector

Multi-scan (CrysAlis PRO; Rigaku OD, 2015)

$0.485,0.980$

$5452,2070,1778$

0.031

0.617

$0.032,0.070,1.11$

2070

139

5

$\mathrm{H}$ atoms treated by a mixture of independent and constrained refinement

$0.62,-0.50$

$\Delta \rho_{\max }, \Delta \rho_{\min }\left(\mathrm{e} \AA^{-3}\right)$

$0.44,-0.48$

Computer programs: CrysAlis PRO (Rigaku OD, 2015), SHELXS97 (Sheldrick, 2008), SIR92 (Altomare et al., 1993), SHELXL97 (Sheldrick, 2008) within WinGX (Farrugia, 2012), and PLATON (Spek, 2009).

$\left.\left(\mathrm{NO}_{3}\right)_{2}\left(4-\mathrm{NH}_{3} \mathrm{C}_{6} \mathrm{H}_{4} \mathrm{AsO}_{3} \mathrm{H}\right)\right]_{n}$ (Lesikar-Parrish et al., 2013), and less commonly with the monoanionic zwitterionic ligand species, for example, $\left\{\left[\mathrm{Zn}_{2} \mathrm{Cl}_{2}\left(4-\mathrm{NH}_{3} \mathrm{C}_{6} \mathrm{H}_{4} \mathrm{AsO} \mathrm{O}_{3}\right)\right] \mathrm{Cl} \cdot 2 \mathrm{H}_{2} \mathrm{O}\right\}_{n}$ (Lesikar-Parrish et al., 2013).

More commonly, the monoanionic nonzwitterionic ligand species hydrogen (4-aminophenyl)arsonate $\left(\mathrm{PARSH}^{-}\right)$is present in metal complexes, although structures of single-metal complexes, $c f$. those with more than one metal, are not very common in the Cambridge Structural Database (CSD; Groom et al., 2016). Examples of mixed-metal polyoxidometallic structures, such as those with $\mathrm{Mo} / \mathrm{Ag}, \mathrm{Mo} / \mathrm{Cu}, \mathrm{W} / \mathrm{Na}$ and $\mathrm{V} / \mathrm{Na}$, are known (Breen \& Schmitt, 2008; Johnson et al., 2002).

We have previously reported the crystal structures of the hydrogen $p$-arsanilate complex salts with alkali metal complex salts, namely $\left[\mathrm{Na}(\mathrm{PARSH})\left(\mathrm{H}_{2} \mathrm{O}\right)_{2}\right]_{n}$ (Smith \& Wermuth, 2014) and the isotypic $\mathrm{K}, \mathrm{Rb}$ and $\mathrm{Cs}$ complexes (Smith \& Wermuth, 2017a), as well as the structures of the alkaline earth complex salts (Smith \& Wermuth, 2017b). For the first set, having the general formula $\left[\left(M^{+}\right)_{2} \cdot 2\left(\mathrm{C}_{6} \mathrm{H}_{6} \mathrm{AsNO}_{3} \mathrm{H}^{-}\right) \cdot 3\left(\mathrm{H}_{2} \mathrm{O}\right)\right]_{n}$, all the species are involved in bonding with the metal ion, with the
$\mathrm{PARSH}^{-}$anion bonding only through the bridging arsonate O-atom donors, forming two-dimensional layered coordination polymeric substructures. The structure of the $\mathrm{NH}_{4}{ }^{+}$salt (a monohydrate) is also known (Smith \& Wermuth, 2014).

Among the alkaline earth set, the Mg complex salt differs from the other members in having the commonly found $\left[\mathrm{Mg}\left(\mathrm{H}_{2} \mathrm{O}\right)_{6}\right]^{2+}$ cation in a complex salt, with the anionic hydrogen $p$-arsanilate species uncoordinated, the structure being essentially isotypic with the $\mathrm{Mn}^{2+}$ salt structure (Smith \& Wermuth, 2016). In the other three coordination polymeric structures of the alkaline earth set, the $\mathrm{PARSH}^{-}$ligands are coordinated and bridging, viz. $\left\{\left[\mathrm{Ca}(\mathrm{PARSH})_{2}\left(\mathrm{H}_{2} \mathrm{O}\right)_{2}\right] \cdot 2 \mathrm{H}_{2} \mathrm{O}\right\}_{n}$, (1), $\left[\mathrm{Sr}(\mathrm{PARSH})_{2}\left(\mathrm{H}_{2} \mathrm{O}\right)_{3}\right]_{n},(2)$, and isotypic $\left[\mathrm{Ba}(\mathrm{PARSH})_{2^{-}}\right.$ $\left.\left(\mathrm{H}_{2} \mathrm{O}\right)_{3}\right]_{n},(3)$.

Although the monoanionic hydrogen $p$-arsanilate species $\left(\mathrm{PARSH}^{-}\right)$is involved in numerous metal coordination environments, it is surprising that examples of the protonated 4-arsonoanilinate $\left(\mathrm{PARSH}_{3}{ }^{+}\right.$) species are absent from the CSD. It was considered that in the presence of strong acids, including organic acid analogues, protonation should readily 
be achieved. We therefore tried a number of preparations involving $\mathrm{PARSH}_{2}$ with metal salts under various acidic aqueous conditions and the following compounds were obtained and their structures reported herein: 4-arsonoanilinium chloride, $\mathrm{PARSH}_{3}{ }^{+} \cdot \mathrm{Cl}^{-}$, (I); the double salt hexaaquacopper(II) bis(4-arsonoanilinium) disulfate dihydrate, $\left(\mathrm{PARSH}_{3}\right)_{2}\left[\mathrm{Cu}\left(\mathrm{H}_{2} \mathrm{O}\right)_{6}\right]\left(\mathrm{SO}_{4}\right)_{2} \cdot 2 \mathrm{H}_{2} \mathrm{O}$, (II); poly[bis(4-arsonoanilinium) [tetra- $\mu$-chlorido-cuprate(II)]], $\left\{\left(\mathrm{PARSH}_{3}\right)_{2}\left[\mathrm{CuCl}_{4}\right]\right\}_{n}$, (III); and poly[bis(4-arsonoanilinium) [tetra- $\mu$-chlorido-cadmate(II)]], $\left\{\left(\mathrm{PARSH}_{3}\right)_{2}\left[\mathrm{CdCl}_{4}\right]\right\}_{n},(\mathrm{IV})$.
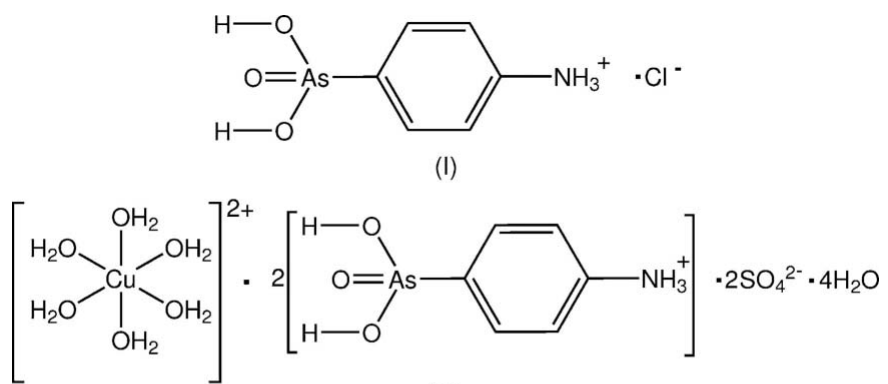

(II)

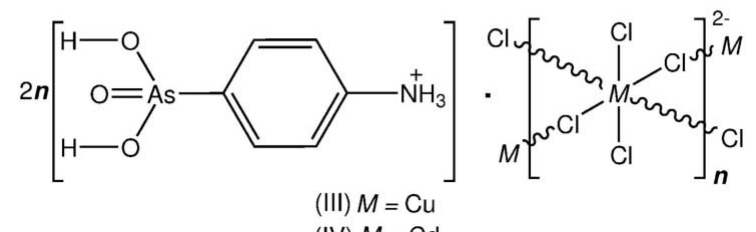

(IV) $M=\mathrm{Cd}$

\section{Experimental}

\subsection{Synthesis and crystallization}

Compounds (II) and (III) were synthesized by heating together for $5 \mathrm{~min}, 1 \mathrm{mmol}$ quantities of (4-aminophenyl)arsonic acid $\left(\mathrm{PARSH}_{2}\right)$ and $0.5 \mathrm{mmol}$ of either $\mathrm{CuSO}_{4} \cdot 5 \mathrm{H}_{2} \mathrm{O}$ or $\mathrm{CuCl}_{2}$, respectively, in $20 \mathrm{ml}$ of $50 \%(v / v)$ ethanol/water. For (IV), a similar procedure to that used for (III) was employed using $\mathrm{CdCO}_{3}$ with the addition of excess $\mathrm{HCl}$. Room-temperature evaporation of the solutions gave thin pale-blue crystal plates of (II), green crystal plates of (III) and colourless crystal plates of (IV), from which specimens were cleaved for the X-ray analyses. Salt (I) was obtained from the attempted preparation of a cobalt derivative of $\mathrm{PARSH}_{2}$ using the above procedure with cobalt(II) acetate but with the addition of $\mathrm{HCl}$ to achieve dissolution of the initially formed precipitate. Colourless crystal prisms were formed after roomtemperature evaporation.

\subsection{Refinement}

Crystal data, data collection and structure refinement details are summarized in Table 1 . $\mathrm{H}$ atoms potentially involved in hydrogen-bonding interactions were located by difference methods but their positional parameters were constrained in the refinement, with $\mathrm{N}-\mathrm{H}=0.88$ (2) $\AA$ and $\mathrm{O}-\mathrm{H}=0.86$ (2) $\AA$ [or 0.90 (2) $\AA$ for $(\mathrm{I})$ ], and with $U_{\text {iso }}(\mathrm{H})=$ $1.2 U_{\text {eq }}(\mathrm{N})$ or $1.5 U_{\text {eq }}(\mathrm{O})$. Other $\mathrm{H}$ atoms were included in the refinement at calculated positions $(\mathrm{C}-\mathrm{H}=0.95 \AA)$ and treated as riding, with $U_{\text {iso }}(\mathrm{H})=1.2 U_{\text {eq }}(\mathrm{C})$.

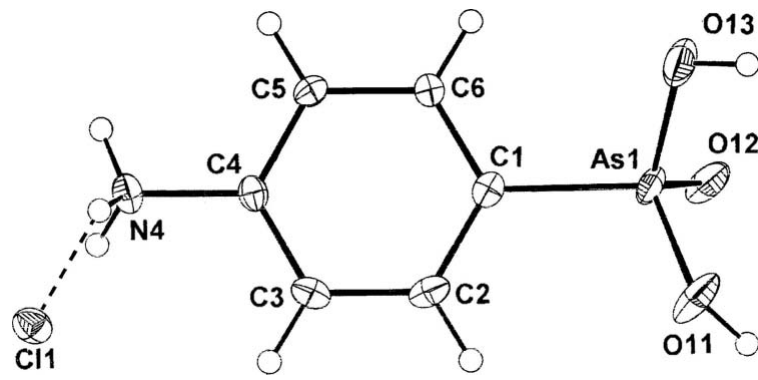

Figure 1

The molecular configuration and atom-numbering scheme for the 4-arsonoanilinium cation and the chloride anion in the asymmetric unit of (I), with displacement ellipsoids drawn at the $40 \%$ probability level and the hydrogen bond shown as a dashed line.

\section{Results and discussion}

In structures (I)-(IV), the protonated 4-arsonoanilinium cationic species, i.e. 4-arsonoanilinium or $\mathrm{PARSH}_{3}{ }^{+}$, is present, namely as a discrete cation in (I), as linker cations between $\left[\mathrm{Cu}\left(\mathrm{H}_{2} \mathrm{O}\right)_{6}\right]^{2+}$ cation and sulfate anion layers in double salt (II), and between polymeric anionic $\left\{\left[\mathrm{CuCl}_{4}\right]^{2-}\right\}_{n}$ layers in (III) or $\left\{\left[\mathrm{CdCl}_{4}\right]^{2-}\right\}_{n}$ layers in the isotypic complex salt (IV). The presence of the cation is confirmed on the basis of chemical stoichiometry, as well as on the As1-O bond lengths [As1-O11, As1-O13 and As1 $=\mathrm{O} 12$ are, respectively, $1.688(3), 1.701(2)$ and 1.648 (2) $\AA$ for (I); $1.7046(18)$, 1.702 (2) and 1.6395 (19) $\AA$ for (II); 1.700 (2), 1.706 (3) and 1.644 (2) $\AA$ for (III); and 1.697 (3), 1.710 (3) and 1.648 (3) $\AA$ for (IV)]. These values compare with the values of 1.737 (6), 1.656 (3) and 1.669 (6) $\AA$ in the parent acid zwitterion (Nuttall \& Hunter, 1996) and the values of 1.747 (3), 1.672 (3) and 1.677 (2) $\AA$ in the monoanionic ligand in the $\mathrm{Na}$ complex (Smith \& Wermuth, 2014). There are no examples of the cationic $\mathrm{PARSH}_{3}{ }^{+}$species in the $\mathrm{CSD}$, nor are there any examples of compounds with the the analogous protonated (4-aminophenyl)phosphonic acid. We have also found the

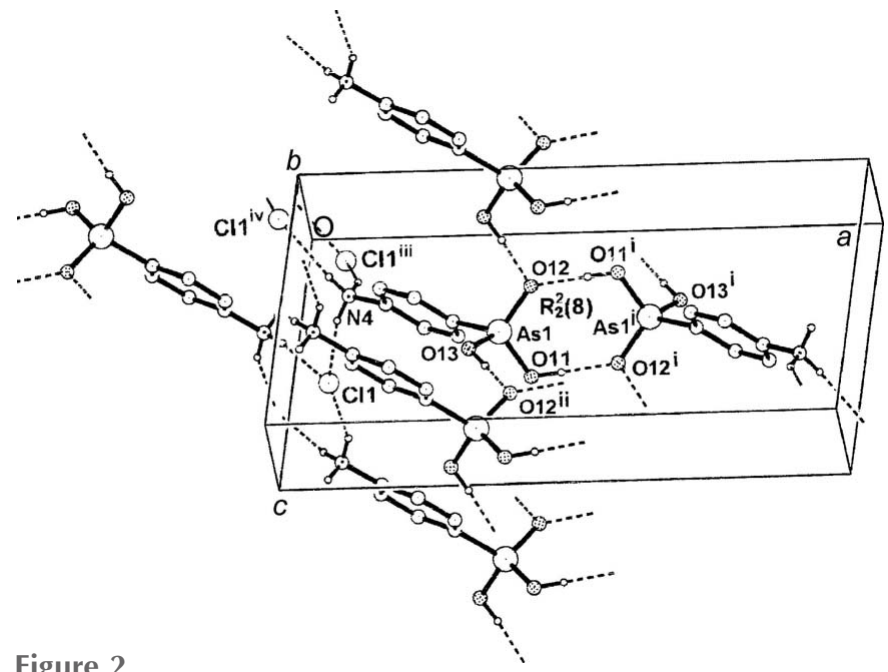

Figure 2

The packing in the unit cell of (I), viewed along the $b$-axial direction, showing the associated cation-linked chloride layers linked peripherally across $a$ by hydrogen bonds (dashed lines) involving the 4-arsonoanilinium cations. The symmetry codes are as in Table 2 . 
Table 2

Hydrogen-bond geometry $\left(\AA,^{\circ}\right)$ for (I).

\begin{tabular}{|c|c|c|c|c|}
\hline$D-\mathrm{H} \cdots A$ & $D-\mathrm{H}$ & $\mathrm{H} \cdots A$ & $D \cdots A$ & $D-\mathrm{H} \cdots A$ \\
\hline $\mathrm{O} 11-\mathrm{H} 11 \cdots \mathrm{O} 12^{\mathrm{i}}$ & $0.88(2)$ & $1.68(2)$ & $2.563(3)$ & $178(5)$ \\
\hline $\mathrm{O} 13-\mathrm{H} 13 \cdots \mathrm{O} 12^{\mathrm{ii}}$ & $0.87(3)$ & $1.73(3)$ & $2.582(3)$ & $167(4)$ \\
\hline $\mathrm{N} 4-\mathrm{H} 41 \cdots \mathrm{Cl} 1^{\mathrm{iii}}$ & $0.87(2)$ & $2.29(2)$ & $3.073(2)$ & $151(3)$ \\
\hline $\mathrm{N} 4-\mathrm{H} 42 \cdots \mathrm{Cl} 1$ & $0.87(2)$ & $2.27(2)$ & $3.091(2)$ & $158(2)$ \\
\hline $\mathrm{N} 4-\mathrm{H} 43 \cdots \mathrm{Cl} 1^{\mathrm{iv}}$ & $0.87(2)$ & $2.30(2)$ & $3.160(3)$ & $170(2)$ \\
\hline
\end{tabular}

Symmetry codes: (i) $-x+1,-y+1,-z+1$; (ii) $x,-y+\frac{3}{2}, z+\frac{1}{2}$; (iii) $x,-y-\frac{1}{2}, z-\frac{1}{2}$; (iv) $-x, y+\frac{1}{2},-z+\frac{1}{2}$.

Table 3

Selected bond lengths $(\AA)$ for (II).

\begin{tabular}{llll}
\hline $\mathrm{Cu} 1-\mathrm{O} 3 W$ & $2.013(2)$ & $\mathrm{Cu} 1-\mathrm{O} 2 W$ & $1.946(2)$ \\
$\mathrm{Cu} 1-\mathrm{O} 1 W$ & $2.2702(18)$ & & \\
\hline
\end{tabular}

Table 4

Hydrogen-bond geometry $\left(\AA,^{\circ}\right)$ for (II).

\begin{tabular}{|c|c|c|c|c|}
\hline$D-\mathrm{H} \cdots A$ & $D-\mathrm{H}$ & $\mathrm{H} \cdots A$ & $D \cdots A$ & $D-\mathrm{H} \cdots A$ \\
\hline $\mathrm{O} 11-\mathrm{H} 11 \cdots \mathrm{O}^{\mathrm{ii}}$ & $0.83(3)$ & $1.76(3)$ & $2.582(3)$ & $167(3)$ \\
\hline $\mathrm{O} 13-\mathrm{H} 13 \cdots \mathrm{O} 4 W$ & $0.85(2)$ & $1.79(2)$ & $2.631(3)$ & $174(3)$ \\
\hline $\mathrm{O} 1 W-\mathrm{H} 11 W \cdots \mathrm{O} 4^{\mathrm{iii}}$ & $0.83(3)$ & $1.92(3)$ & $2.745(3)$ & $171(4)$ \\
\hline $\mathrm{O} 1 W-\mathrm{H} 12 W \cdots \mathrm{O} 2^{\mathrm{ii}}$ & $0.81(3)$ & $1.90(3)$ & $2.703(3)$ & $176(3)$ \\
\hline $\mathrm{O} 2 W-\mathrm{H} 21 W \cdots \mathrm{O} 4 W^{\mathrm{iv}}$ & $0.85(3)$ & $1.86(3)$ & $2.698(3)$ & $170(3)$ \\
\hline $\mathrm{O} 2 W-\mathrm{H} 22 W \cdots \mathrm{O} 12$ & $0.83(3)$ & $1.84(3)$ & $2.667(3)$ & $173(3)$ \\
\hline $\mathrm{O} 3 W-\mathrm{H} 31 W \cdots \mathrm{O} 1^{\mathrm{v}}$ & $0.82(2)$ & $2.00(2)$ & $2.792(3)$ & $161(3)$ \\
\hline $\mathrm{O} 3 W-\mathrm{H} 32 W \cdots \mathrm{O} 1^{\mathrm{vi}}$ & $0.84(2)$ & $1.94(2)$ & $2.780(2)$ & $176(4)$ \\
\hline $\mathrm{O} 4 W-\mathrm{H} 41 W \cdots \mathrm{O} 1 W$ & $0.82(3)$ & $2.09(3)$ & $2.858(3)$ & $157(3)$ \\
\hline $\mathrm{O} 4 W-\mathrm{H} 42 W \cdots \mathrm{O} 2^{\text {vii }}$ & $0.82(3)$ & $1.96(3)$ & $2.753(3)$ & $164(3)$ \\
\hline $\mathrm{N} 4-\mathrm{H} 41 \cdots \mathrm{O} 4^{\mathrm{viii}}$ & $0.89(3)$ & $1.85(3)$ & $2.726(3)$ & $169(3)$ \\
\hline $\mathrm{N} 4-\mathrm{H} 42 \cdots \mathrm{O} 3$ & $0.89(2)$ & $1.88(2)$ & $2.767(3)$ & $175(2)$ \\
\hline $\mathrm{N} 4-\mathrm{H} 43 \cdots \mathrm{O} 12^{\mathrm{ix}}$ & $0.90(2)$ & $1.80(2)$ & $2.680(3)$ & $166(2)$ \\
\hline $\mathrm{C} 2-\mathrm{H} 2 \cdots \mathrm{O} 11^{\mathrm{iv}}$ & 0.95 & 2.49 & $3.385(3)$ & 157 \\
\hline
\end{tabular}

Symmetry codes: (ii) $-x+1, y-\frac{1}{2},-z+\frac{1}{2}$; (iii) $x-1,-y+\frac{1}{2}, z+\frac{1}{2}$; (iv) $x,-y+\frac{1}{2}, z-\frac{1}{2}$; (v) $x-1, y, z$; (vi) $x-1,-y+\frac{1}{2}, z-\frac{1}{2}$; (vii) $-x+1,-y+1,-z$; (viii) $x,-y+\frac{1}{2}, z+\frac{1}{2}$; (ix) $-x+1,-y,-z$.

$\mathrm{PARSH}_{3}{ }^{+}$species in the crystal structures of 1:1 protontransfer compounds of $p$-arsanilic acid with strong organic acids, for example, picric acid, 3,5-dinitrosalicylic acid, 5-sulfosalicylic acid and $p$-toluenesulfonic acid (Smith \& Wermuth, 2017c).

In the crystal structure of (I) (Fig. 1), the $\mathrm{PARSH}_{3}{ }^{+}$cations are linked through arsonate $\mathrm{O} 11-\mathrm{H} 11 \cdots \mathrm{O} 12^{\mathrm{i}}$ and $\mathrm{O} 13-$ H13...O12 $2^{\text {ii }}$ hydrogen bonds (see Table 2 for details and symmetry codes), generating two-dimensional layered structures lying parallel to (100). The first of these interactions forms centrosymmetric $R_{2}^{2}(8)$ ring motifs. In the crystal, the layers are linked across $a$ through anilinium $\mathrm{N}-\mathrm{H} \cdots \mathrm{Cl}$ hydrogen bonds (Table 1), giving a three-dimensional structure (Fig. 2). Weak inter-ring $\pi-\pi$ interactions are also present [minimum ring-centroid separation $=2.8304$ (16) $\AA$ ] .

In the structure of the $\mathrm{Cu}^{\mathrm{II}}$ double salt (II) (Fig. 3), the centrosymmetric $\left[\mathrm{Cu}\left(\mathrm{H}_{2} \mathrm{O}\right)_{6}\right]^{2+}$ cation is accompanied by two inversion-related $\mathrm{PARSH}_{3}{ }^{+}$cations, together with two similarly related sulfate dianions and two water molecules of solvation $\left[\mathrm{O} 4 W\right.$ and $\mathrm{O} 4 W^{\mathrm{i}}$; symmetry code: (i) $\left.-x,-y,-z\right]$. The $\mathrm{Cu}-\mathrm{OW}$ bond lengths in the slightly tetragonally distorted octahedral coordination polyhedron are $1.946(2)$

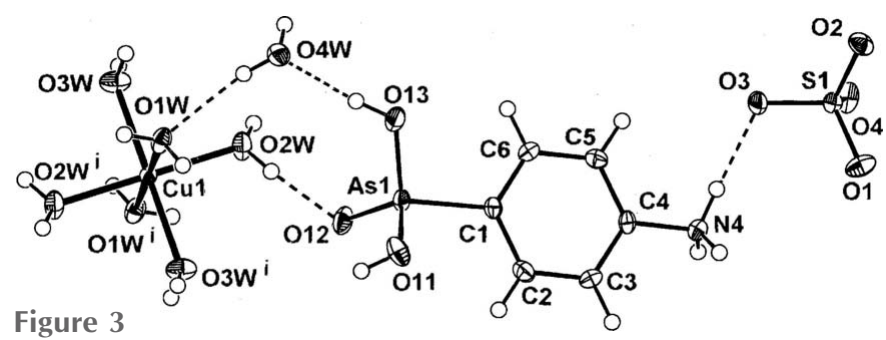

The molecular configuration and atom-numbering scheme for the complex cation, the 4-arsonoanilinium cation, the sulfate anion and the water molecule of solvation $(\mathrm{O} 1 W)$ in the asymmetric unit of (II). The $\mathrm{Cu}^{2+}$ ion sits on a crystallographic centre of inversion and the asymmetric unit contains half the $\left[\mathrm{Cu}\left(\mathrm{H}_{2} \mathrm{O}\right)_{6}\right]^{2+}$ ion, one 4-arsonoanilinium cation, a sulfate dianion and a solvent water molecule. Non-H atoms are shown as $40 \%$ probability displacement ellipsoids. Hydrogen-bonding interactions are shown as dashed lines. [Symmetry code: (i) $-x,-y,-z$.]

and 2.013 (2) (equatorial), and 2.2702 (18) $\AA$ (axial) (Table 3). The $\left[\mathrm{Cu}\left(\mathrm{H}_{2} \mathrm{O}\right)_{6}\right]^{2+}$ cation is a very common counter-ion in $\mathrm{Cu}^{\mathrm{II}}$ complex structures, but no examples involving arsonates and only a few involving analogous phosphonates are known, for example, in a bridged (2-pyridyl $\mathrm{N}$-oxide)phosphonate complex (Ma et al., 2007). The amine $\mathrm{N}$ group of the $\mathrm{PARSH}_{3}{ }^{+}$ cation is not involved in bonding to the metal atom, unlike that found in a number of $p$-arsanilate complexes, for example, in a second $\mathrm{Zn}$ structure (Lin et al., 2012).

In the crystal of (II), the molecular species, including the coordinated water ligands, are involved in $\mathrm{O}-\mathrm{H} \cdots \mathrm{O}$ and $\mathrm{N}-\mathrm{H} \cdots \mathrm{O}$ hydrogen-bonding interactions with arsonate, sulfate and water O-atom acceptors (Table 4). Among these interactions is a cyclic $R_{3}^{3}(10)$ motif involving all but the sulfate anion, best seen in Fig. 3. Two-dimensional layered substructures lying parallel to (100) are linked across $a$ through $\mathrm{PARSH}_{3}{ }^{+} \mathrm{O}-\mathrm{H} \cdots \mathrm{O}$ and $\mathrm{N}-\mathrm{H} \cdots \mathrm{O}$ hydrogen bonds, giving

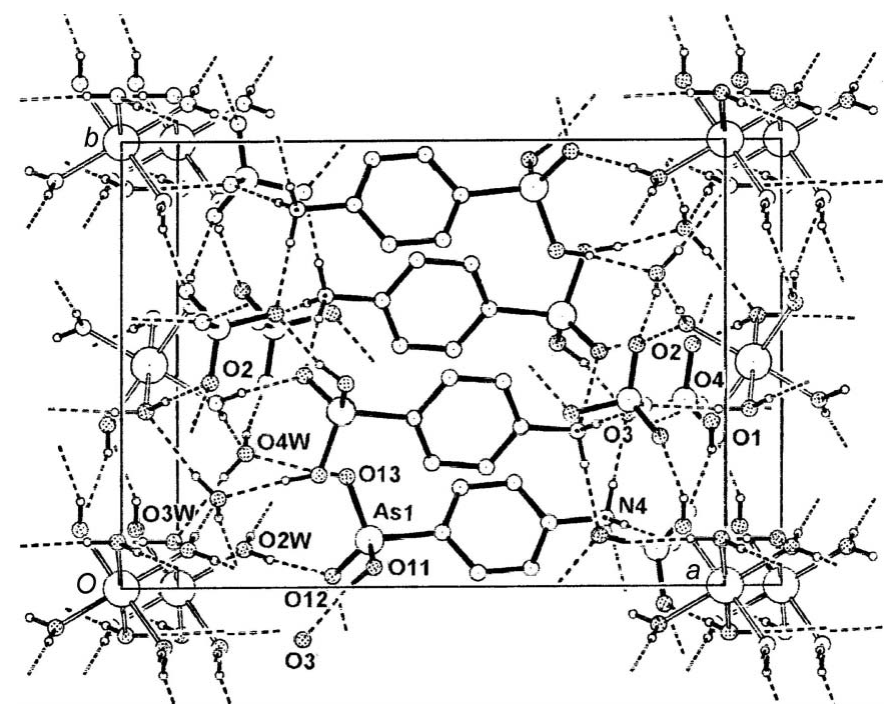

Figure 4

The packing in the unit cell of (II), viewed along the $b$-axial direction, showing the associated $\left[\mathrm{Cu}\left(\mathrm{H}_{2} \mathrm{O}\right)_{6}\right]^{2+}$ cation layers linked peripherally across $a$ by hydrogen bonds involving the 4-arsonoanilinium cations, the sulfate anions and the water molecules of solvation. Hydrogen-bonding interactions are shown as dashed lines and aromatic $\mathrm{H}$ atoms have been omitted. Generic atom labels without symmetry codes have been used. 
Table 5

Selected bond lengths $(\AA)$ for (III).

\begin{tabular}{llll}
\hline $\mathrm{Cu} 1-\mathrm{Cl} 2^{\mathrm{ii}}$ & $2.9833(9)$ & $\mathrm{Cu} 1-\mathrm{Cl} 2$ & $2.2990(9)$ \\
$\mathrm{Cu} 1-\mathrm{Cl} 1$ & $2.2826(8)$ & $\mathrm{Cu} 1-\mathrm{Cl} 2$ & $2.9833(9)$ \\
\hline
\end{tabular}

Symmetry codes: (ii) $-x+\frac{3}{2}, y-\frac{1}{2}, z$; (iii) $x-\frac{1}{2},-y+\frac{3}{2},-z+1$.

Table 6

Selected bond lengths ( $)$ ) for (IV).

\begin{tabular}{llll}
\hline $\mathrm{Cd} 1-\mathrm{Cl} 2^{\mathrm{ii}}$ & $2.6931(10)$ & $\mathrm{Cd} 1-\mathrm{Cl} 2$ & $2.6820(10)$ \\
$\mathrm{Cd} 1-\mathrm{Cl} 1$ & $2.5232(12)$ & $\mathrm{Cd} 1-\mathrm{Cl} 2^{\mathrm{iii}}$ & $2.6931(10)$ \\
\hline
\end{tabular}

Symmetry codes: (ii) $-x+\frac{3}{2}, y-\frac{1}{2}, z$; (iii) $x-\frac{1}{2},-y+\frac{3}{2},-z+1$.

Table 7

Hydrogen-bond geometry $\left(\AA,^{\circ}\right)$ for (III).

\begin{tabular}{|c|c|c|c|c|}
\hline$D-\mathrm{H} \cdots A$ & $D-\mathrm{H}$ & $\mathrm{H} \cdots A$ & $D \cdots A$ & $D-\mathrm{H} \cdots A$ \\
\hline $\mathrm{O} 11-\mathrm{H} 11 \cdots \mathrm{O} 12^{\mathrm{iv}}$ & $0.84(4)$ & $1.78(4)$ & $2.609(4)$ & $170(3)$ \\
\hline $\mathrm{O} 13-\mathrm{H} 13 \cdots \mathrm{O} 12^{\mathrm{v}}$ & $0.85(4)$ & $1.79(4)$ & $2.610(4)$ & $162(4)$ \\
\hline $\mathrm{N} 4-\mathrm{H} 41 \cdots \mathrm{Cl} 1^{\mathrm{ii}}$ & $0.88(2)$ & $2.38(2)$ & $3.235(4)$ & $163(4)$ \\
\hline $\mathrm{N} 4-\mathrm{H} 42 \cdots \mathrm{Cl}^{\mathrm{vi}}$ & $0.87(4)$ & $2.47(4)$ & $3.301(4)$ & $161(3)$ \\
\hline 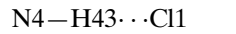 & $0.89(3)$ & $2.39(2)$ & $3.208(4)$ & $153(3)$ \\
\hline $\mathrm{C} 6-\mathrm{H} 6 \cdots \mathrm{O} 13^{\mathrm{ii}}$ & 0.95 & 2.40 & $3.268(5)$ & 152 \\
\hline
\end{tabular}

Symmetry codes: (ii) $-x+\frac{3}{2}, y-\frac{1}{2}, z$; (iv) $x+\frac{1}{2}, y,-z+\frac{1}{2}$; (v) $-x+2, y+\frac{1}{2},-z+\frac{1}{2}$; (vi) $x+\frac{1}{2},-y+\frac{3}{2},-z+1$.

an overall three-dimensional supramolecular structure (Fig. 4). No reasonable ring-ring interactions are present [minimum ring-centroid separation $=3.9829$ (15) A] .

In the $\mathrm{CuCl}_{6}$ coordination polyhedron of (III) (Fig. 5), four of the $\mathrm{Cl}$ ligands are related by inversion, i.e. two monodentate $\left[\mathrm{Cu} 1-\mathrm{Cl} 1\right.$ and $\mathrm{Cu} 1-\mathrm{Cl}^{\mathrm{i}}=2.2826$ (8) $\AA$; symmetry code: (i) $-x+1,-y+1,-z+1]$ and two bridging [ $\mathrm{Cu} 1-\mathrm{Cl} 2$ and $\mathrm{Cu} 1-\mathrm{Cl} 2^{\mathrm{i}}=2.2990$ (9) $\AA$ ], while two longer axial bonds are from bridging $\mathrm{Cl} 2$ donors $\left[\mathrm{Cl} 2^{\mathrm{ii}}\right.$ and inversion-related $\mathrm{Cl} 2{ }^{\mathrm{iii}}$, 2.9833 (9) А; see Table 5 for symmetry codes].

$\mathrm{Cd}^{\mathrm{II}}$ compound (IV) (Fig. 6) is isotypic with copper(II) complex (III) (Fig. 7) and the basic description of the metalchloride bonding in the coordination polymeric structure (Tables 5 and 6) and hydrogen bonding (Tables 7 and 8) are essentially the same. The major difference is seen in the $\mathrm{Cd}-\mathrm{Cl}$ bond lengths in the $\mathrm{CdCl}_{6}$ coordination polyhedron of the complex repeat unit (Table 6), which are more regular [range 2.5232 (12)-2.6931 (10) A] compared to those in (III)

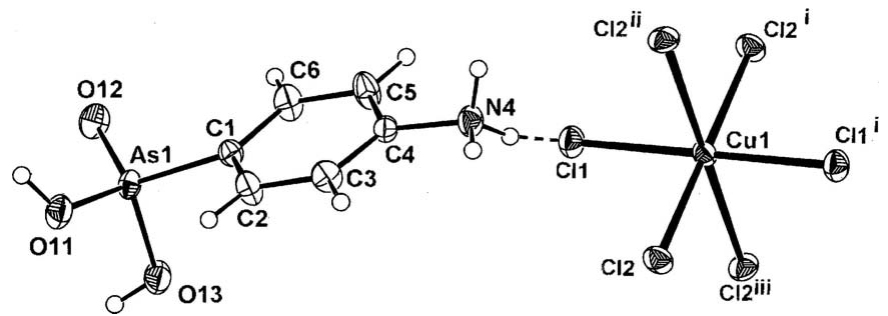

Figure 5

The molecular configuration and atom-numbering scheme for the complex unit in (III). The anionic $\mathrm{CuCl}_{6}$ complex units comprise four inversion-related $\mathrm{Cl}$ donors and two $\mathrm{Cl}$ donors in the polymer extensions. Non-H atoms are shown as $40 \%$ probability displacement ellipsoids. The dashed line represents the $\mathrm{N}-\mathrm{H} \cdots \mathrm{Cl}$ hydrogen bond. [Symmetry codes: (i) $-x+1,-y+1,-z+1$; (ii) $-x+\frac{3}{2}, y-\frac{1}{2}, z$; (iii) $x-\frac{1}{2},-y+\frac{3}{2},-z+1$.]
Table 8

Hydrogen-bond geometry $\left(\AA,^{\circ}\right)$ for (IV).

\begin{tabular}{lllll}
\hline$D-\mathrm{H} \cdots A$ & $D-\mathrm{H}$ & $\mathrm{H} \cdots A$ & $D \cdots A$ & $D-\mathrm{H} \cdots A$ \\
\hline $\mathrm{O} 11-\mathrm{H} 11 \cdots \mathrm{O} 12^{\text {iv }}$ & $0.86(4)$ & $1.74(4)$ & $2.597(4)$ & $175(3)$ \\
$\mathrm{O}^{\mathrm{v}}-\mathrm{H} 13 \cdots \mathrm{O} 12^{\mathrm{v}}$ & $0.88(4)$ & $1.75(4)$ & $2.596(4)$ & $160(4)$ \\
$\mathrm{N}^{2}-\mathrm{H} 41 \cdots \mathrm{Cl} 1^{\mathrm{ii}}$ & $0.88(2)$ & $2.31(2)$ & $3.178(4)$ & $170(5)$ \\
$\mathrm{N} 4-\mathrm{H} 42 \cdots \mathrm{Cl} 2^{\mathrm{vi}}$ & $0.90(4)$ & $2.37(4)$ & $3.257(4)$ & $168(3)$ \\
$\mathrm{N} 4-\mathrm{H} 43 \cdots \mathrm{Cl} 1$ & $0.90(3)$ & $2.30(2)$ & $3.150(4)$ & $158(4)$ \\
$\mathrm{C} 6-\mathrm{H} 6 \cdots \mathrm{O} 13^{\text {ii }}$ & 0.95 & 2.41 & $3.246(5)$ & 146 \\
\hline
\end{tabular}

Symmetry codes: (ii) $-x+\frac{3}{2}, y-\frac{1}{2}, z$; (iv) $x+\frac{1}{2}, y,-z+\frac{1}{2}$; (v) $-x+2, y+\frac{1}{2},-z+\frac{1}{2}$; (vi) $x+\frac{1}{2},-y+\frac{3}{2},-z+1$.

(Table 5). A minor anomaly in the comparison of the two structures is that in the smaller unit cell of (III), the $a$ cell parameter [7.6315 (4) $\AA$ ] is slightly longer than that of (IV) [7.5525 (4) $\AA$ ] and may be due to the larger axial $\mathrm{Cu}-\mathrm{Cl} 2^{\mathrm{ii}}$ and $\mathrm{Cu}-\mathrm{Cl}^{\mathrm{iii}}$ bond lengths in the tetragonally distorted complex unit.

A two-dimensional coordination polymeric network substructure lying parallel to (001) is generated in both (III) and (IV) through centrosymmetric cyclic eight-membered chloride-bridged units (Fig. 7). In the crystal, the polymer layers are linked across [001] by a number of bridging hydrogen bonds involving $\mathrm{N}-\mathrm{H} \cdots \mathrm{Cl}$ interactions from headto-head $\mathrm{O}-\mathrm{H}$. . O O-linked 4-arsonoanilinium cations (Tables 7 and 8). An overall three-dimensional network structure is

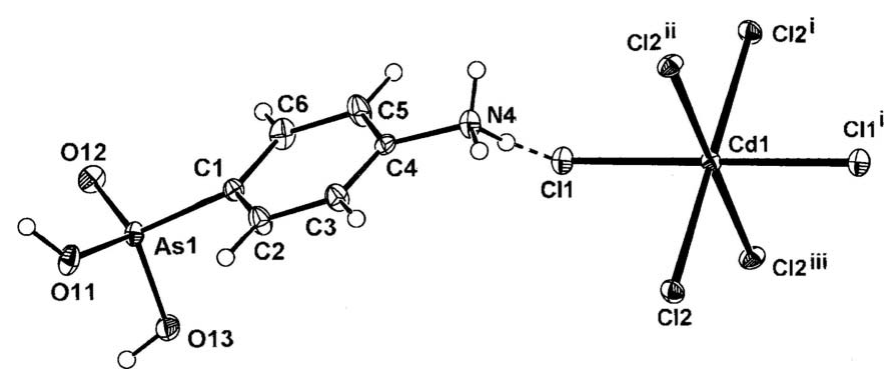

Figure 6

The molecular configuration and atom-numbering scheme for the complex unit in (IV), with non- $\mathrm{H}$ atoms shown as $40 \%$ probability displacement ellipsoids. The anionic $\mathrm{CdCl}_{6}$ complex units have the same symmetry codes as shown for the isotypic $\mathrm{Cu}^{2+}$ complex (III) in Fig. 5. The dashed line represents the $\mathrm{N}-\mathrm{H} \cdots \mathrm{Cl}$ hydrogen bond.

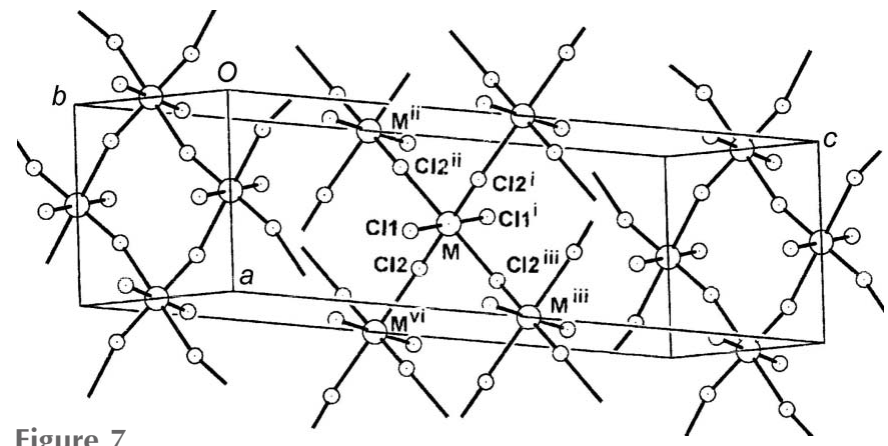

Figure 7

The two-dimensional anionic coordination polymeric sheet substructures of (III) and (IV), which lie parallel to (001) in the unit cell, with the 4-arsonoanilinium cations removed. $M$ represents $\mathrm{Cu}^{2+}$ for (III) and $\mathrm{Cd}^{2+}$ for (IV). The $\mathrm{PARSH}_{3}{ }^{+}$cations have been omitted. (For symmetry codes, see Table 6 and Fig. 5.) 


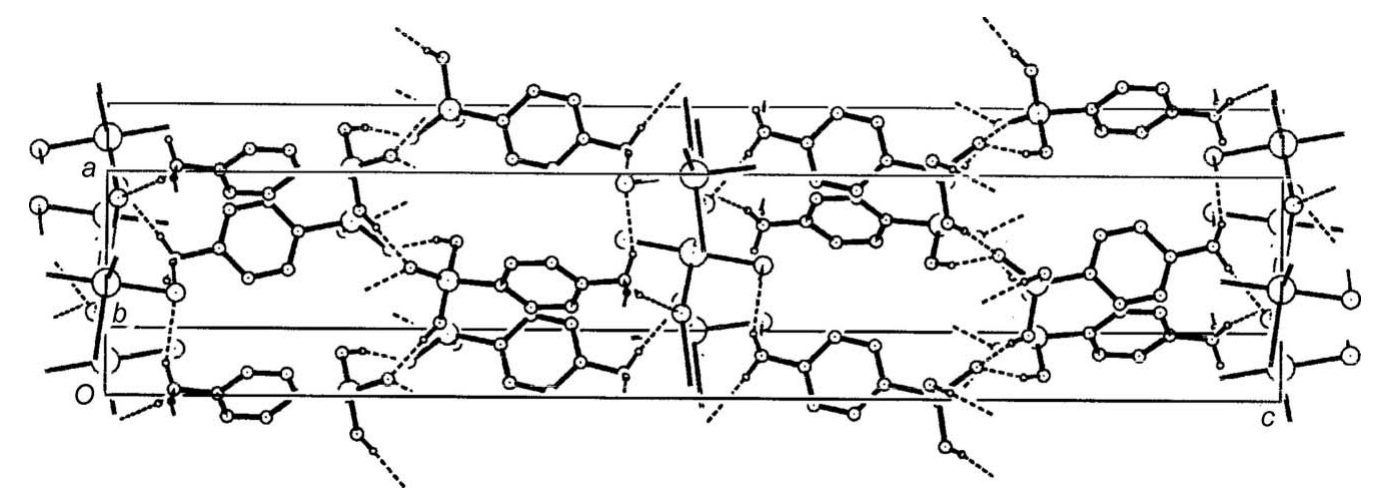

Figure 8

A view of the packing in the unit cells of (III) or (IV), showing the associated cation/anion sheets linked peripherally across $c$ by hydrogen bonds (dashed lines) involving the anilinium groups.

formed (Fig. 8). It should also be noted that the $\mathrm{Cd}^{\mathrm{II}}$ complex reported by Lesikar-Parrish et al. (2013), prepared from $\mathrm{CdCl}_{2}$ using mild aqueous reaction conditions, was $\left[\mathrm{CdCl}_{2}(4-\right.$ $\left.\left.\mathrm{NH}_{3} \mathrm{C}_{6} \mathrm{H}_{4} \mathrm{AsO}_{3} \mathrm{H}\right)\left(\mathrm{H}_{2} \mathrm{O}\right)_{2}\right]_{n}$.

The basic $M-\mathrm{Cl}$ polymeric sheet structures present in both compounds (III) and (IV) are not unusual, with 65 CSD examples present in the case of the less prevalent $\mathrm{Cd}-\mathrm{Cl}$ structure. However, the eight-membered cyclic unit described for (IV) is not so common, more often being four-membered involving di- $\mu_{2}$-chlorido- or tri- $\mu_{2}$-chlorido-bridged rings such as are present in the $\left[\mathrm{CdCl}_{4}\right]^{2-}$ complex substructures in complexes with the methylammonium cation (Pabst et al., 1987) and the 2-amino-4,5-dihydro-3H-1,3-triazolium cation (Kubiak et al., 1983).

The series of structures reported here represent examples having a previously structurally unreported protonated (4-aminophenyl)arsonic acid, the 4-arsonoanilinium cation. These compounds are various, ranging from a simple hydrochloride to a $\mathrm{Cu}^{\mathrm{II}}$ double sulfate salt from reaction with aqueous $\mathrm{CuSO}_{4}$ to counter-cations from the reaction with $\mathrm{CuCl}_{2}$ or $\mathrm{CdCl}_{2}$ in the presence of $\mathrm{HCl}$.

\section{Acknowledgements}

The authors acknowledge support from the Science and Engineering Faculty, Queensland University of Technology and Griffith University.

\section{References}

Altomare, A., Cascarano, G., Giacovazzo, C. \& Guagliardi, A. (1993). J. Appl. Cryst. 26, 343-350.

Breen, J. M. \& Schmitt, W. (2008). Angew. Chem. Int. Ed. 47, 69046908.

Ehrlich, P. \& Bertheim, A. (1907). Ber. Dtsch Chem. Ges. 40, 3292-3297.

Farrugia, L. J. (2012). J. Appl. Cryst. 45, 849-854.

Groom, C. R., Bruno, I. J., Lightfoot, M. P. \& Ward, S. C. (2016). Acta Cryst. B72, 171-179.

Johnson, B. J. S., Schroden, R. C., Zhu, C., Young, V. G. \& Stein, A. (2002). Inorg. Chem. 41, 2213-2218.

Kubiak, M., Glowiak, T. \& Kozlowski, H. (1983). Acta Cryst. C39, 1637-1639.

Lesikar-Parrish, L. A., Neilson, R. H. \& Richards, A. F. (2013). J. Solid State Chem. 198, 424-432.

Lin, W.-Z., Liu, Z.-Q., Huang, X.-H., Li, H.-H., Wu, S.-T. \& Huang, C.-C. (2012). Chin. J. Struct. Chem. 31, 1301-1308.

Ma, Y.-S., Wang, T.-W., Li, Y.-Z. \& Zheng, L.-M. (2007). Inorg. Chim. Acta, 360, 4117-4124.

Nuttall, R. H. \& Hunter, W. N. (1996). Acta Cryst. C52, 1681-1683.

Pabst, I., Fuess, H. \& Bats, J. W. (1987). Acta Cryst. C43, 413-416.

Rigaku OD (2015). CrysAlis PRO. Rigaku Oxford Diffraction Ltd, Yarnton, Oxfordshire, England.

Sheldrick, G. M. (2008). Acta Cryst. A64, 112-122.

Shimada, A. (1961). Bull. Chem. Soc. Jpn, 34, 639-643.

Smith, G. \& Wermuth, U. D. (2014). Acta Cryst. C70, 738-741.

Smith, G. \& Wermuth, U. D. (2016). IUCrData, 1, x161985.

Smith, G. \& Wermuth, U. D. (2017a). Acta Cryst. E73, 203-208.

Smith, G. \& Wermuth, U. D. (2017b). Acta Cryst. C73, 61-67.

Smith, G. \& Wermuth, U. D. (2017c). Unpublished results.

Spek, A. L. (2009). Acta Cryst. D65, 148-155.

Steverding, D. (2010). Parasites Vectors, 3, 15. 


\section{supporting information}

Acta Cryst. (2017). C73, 325-330 [https://doi.org/10.1107/S205322961700314X]

\section{Unusual 4-arsonoanilinium cationic species in the hydrochloride salt of (4- aminophenyl)arsonic acid and formed in the reaction of the acid with copper(II) sulfate, copper(II) chloride and cadmium chloride}

\section{Graham Smith and Urs D. Wermuth}

Computing details

For all compounds, data collection: CrysAlis PRO (Rigaku OD, 2015); cell refinement: CrysAlis PRO (Rigaku OD, 2015); data reduction: CrysAlis PRO (Rigaku OD, 2015). Program(s) used to solve structure: SIR 92 (Altomare et al., 1993) for (I); SHELXS97 (Sheldrick, 2008) for (II), (III); SIR92 (Altomare et al., 1993) for (IV). For all compounds, program(s) used to refine structure: SHELXL97 (Sheldrick, 2008) within WinGX (Farrugia, 2012); molecular graphics: PLATON (Spek, 2009); software used to prepare material for publication: PLATON (Spek, 2009).

(I) 4-Arsonoanilinium chloride

Crystal data

$\mathrm{C}_{6} \mathrm{H}_{9} \mathrm{AsNO}_{3}{ }^{+} \cdot \mathrm{Cl}^{-}$

$M_{r}=253.51$

Monoclinic, $P 2_{1} / c$

Hall symbol: -P 2ybc

$a=16.6534(8) \AA$

$b=7.4129(3) \AA$

$c=7.6073(4) \AA$

$\beta=97.795(4)^{\circ}$

$V=930.44(8) \AA^{3}$

$Z=4$

Data collection

Oxford Diffraction Gemini-S CCD-detector diffractometer

Radiation source: Enhance (Mo) X-ray source Graphite monochromator

Detector resolution: 16.077 pixels $\mathrm{mm}^{-1}$

$\omega$ scans

Absorption correction: multi-scan

(CrysAlis PRO; Rigaku OD, 2015)

$T_{\min }=0.66, T_{\max }=0.98$

Refinement

Refinement on $F^{2}$

Least-squares matrix: full

$R\left[F^{2}>2 \sigma\left(F^{2}\right)\right]=0.028$

$w R\left(F^{2}\right)=0.068$

$S=1.06$
$F(000)=504$

$D_{\mathrm{x}}=1.810 \mathrm{Mg} \mathrm{m}^{-3}$

Mo $K \alpha$ radiation, $\lambda=0.71073 \AA$

Cell parameters from 1528 reflections

$\theta=4.4-29.2^{\circ}$

$\mu=3.91 \mathrm{~mm}^{-1}$

$T=200 \mathrm{~K}$

Plate, colourless

$0.40 \times 0.40 \times 0.15 \mathrm{~mm}$

3922 measured reflections

1820 independent reflections

1601 reflections with $I>2 \sigma(I)$

$R_{\text {int }}=0.026$

$\theta_{\max }=26.0^{\circ}, \theta_{\min }=3.7^{\circ}$

$h=-20 \rightarrow 9$

$k=-8 \rightarrow 9$

$l=-9 \rightarrow 9$

1820 reflections

124 parameters

5 restraints

Primary atom site location: structure-invariant direct methods 
Secondary atom site location: difference Fourier map

Hydrogen site location: inferred from neighbouring sites

$\mathrm{H}$ atoms treated by a mixture of independent and constrained refinement

$$
\begin{aligned}
& w=1 /\left[\sigma^{2}\left(F_{\mathrm{o}}{ }^{2}\right)+(0.0304 P)^{2}+0.3689 P\right] \\
& \quad \text { where } P=\left(F_{\mathrm{o}}^{2}+2 F_{\mathrm{c}}{ }^{2}\right) / 3 \\
& (\Delta / \sigma)_{\max }=0.001 \\
& \Delta \rho_{\max }=0.44 \mathrm{e} \AA^{-3} \\
& \Delta \rho_{\min }=-0.48 \mathrm{e} \AA^{-3}
\end{aligned}
$$

\section{Special details}

Geometry. Bond distances, angles etc. have been calculated using the rounded fractional coordinates. All su's are estimated from the variances of the (full) variance-covariance matrix. The cell esds are taken into account in the estimation of distances, angles and torsion angles

Refinement. Refinement of $\mathrm{F}^{2}$ against ALL reflections. The weighted R-factor $\mathrm{wR}$ and goodness of fit $\mathrm{S}$ are based on $\mathrm{F}^{2}$,

\begin{tabular}{|c|c|c|c|c|}
\hline & $x$ & $y$ & $z$ & $U_{\text {iso }} * / U_{\text {eq }}$ \\
\hline As 1 & $0.37111(2)$ & $0.53013(4)$ & $0.52946(4)$ & 0.0235 \\
\hline O11 & $0.43235(13)$ & 0.4083 & $0.6799(3)$ & $0.0387(8)$ \\
\hline $\mathrm{O} 12$ & $0.41875(13)$ & $0.6107(3)$ & 0.3702 & $0.0345(7)$ \\
\hline $\mathrm{O} 13$ & $0.32856(15)$ & 0.6985 & 0.6375 & $0.0454(8)$ \\
\hline N4 & $0.08067(16)$ & 0.0693 & 0.2459 & $0.0218(8)$ \\
\hline $\mathrm{C} 1$ & $0.28113(17)$ & $0.3841(4)$ & $0.4442(3)$ & $0.0200(8)$ \\
\hline $\mathrm{C} 2$ & $0.28676(18)$ & $0.1973(4)$ & $0.4548(4)$ & $0.0263(9)$ \\
\hline $\mathrm{C} 3$ & $0.22080(19)$ & $0.0936(4)$ & $0.3897(4)$ & $0.0252(9)$ \\
\hline $\mathrm{C} 4$ & $0.15124(17)$ & $0.1775(3)$ & $0.3126(3)$ & $0.0178(8)$ \\
\hline $\mathrm{C} 5$ & $0.14488(18)$ & $0.3635(3)$ & $0.2991(4)$ & $0.0225(8)$ \\
\hline C6 & $0.21088(18)$ & $0.4666(4)$ & $0.3665(4)$ & $0.0246(9)$ \\
\hline $\mathrm{Cl1}$ & $0.05319(5)$ & -0.22825 (9) & $0.51606(9)$ & $0.0245(2)$ \\
\hline $\mathrm{H} 2$ & 0.33570 & 0.14160 & 0.50660 & $0.0310^{*}$ \\
\hline H3 & 0.22330 & -0.03420 & 0.39800 & $0.0300 *$ \\
\hline H5 & 0.09630 & 0.41860 & 0.24480 & $0.0270 *$ \\
\hline H6 & 0.20800 & 0.59440 & 0.35950 & $0.0300 *$ \\
\hline H11 & $0.4836(13)$ & $0.400(5)$ & $0.664(5)$ & $0.0580^{*}$ \\
\hline H13 & $0.363(2)$ & $0.748(5)$ & $0.720(4)$ & $0.0680^{*}$ \\
\hline H41 & $0.090(2)$ & $-0.014(3)$ & $0.171(3)$ & $0.0260 *$ \\
\hline $\mathrm{H} 42$ & 0.0631 (19) & $0.008(3)$ & $0.330(3)$ & $0.0260 *$ \\
\hline $\mathrm{H} 43$ & $0.0432(15)$ & $0.135(3)$ & $0.185(3)$ & $0.0260^{*}$ \\
\hline
\end{tabular}
conventional R-factors $\mathrm{R}$ are based on $\mathrm{F}$, with $\mathrm{F}$ set to zero for negative $\mathrm{F}^{2}$. The threshold expression of $\mathrm{F}^{2}>2$ sigma( $\left.\mathrm{F}^{2}\right)$ is used only for calculating R-factors(gt) etc. and is not relevant to the choice of reflections for refinement. R-factors based on $\mathrm{F}^{2}$ are statistically about twice as large as those based on $\mathrm{F}$, and R- factors based on ALL data will be even larger.

Fractional atomic coordinates and isotropic or equivalent isotropic displacement parameters $\left(\AA^{2}\right)$

Atomic displacement parameters $\left(\AA^{2}\right)$

\begin{tabular}{lllllll}
\hline & $U^{11}$ & $U^{22}$ & $U^{33}$ & $U^{12}$ & $U^{13}$ & $U^{23}$ \\
\hline As1 & $0.0114(2)$ & $0.0300(2)$ & $0.0279(2)$ & $-0.0011(1)$ & $-0.0019(1)$ & $-0.0005(1)$ \\
O11 & $0.0152(12)$ & $0.0649(15)$ & $0.0346(12)$ & $0.0039(11)$ & $-0.0017(10)$ & $0.0195(11)$ \\
O12 & $0.0170(12)$ & $0.0419(12)$ & $0.0441(13)$ & $0.0039(10)$ & $0.0024(10)$ & $0.0197(11)$ \\
O13 & $0.0187(13)$ & $0.0528(15)$ & $0.0621(16)$ & $-0.0012(11)$ & $-0.0035(11)$ & $-0.0324(13)$ \\
N4 & $0.0249(15)$ & $0.0208(13)$ & $0.0189(12)$ & $-0.0069(11)$ & $0.0001(10)$ & $0.0011(10)$ \\
C1 & $0.0163(15)$ & $0.0247(14)$ & $0.0188(13)$ & $-0.0008(12)$ & $0.0015(11)$ & $-0.0004(12)$
\end{tabular}




$\begin{array}{lllllll}\text { C2 } & 0.0206(17) & 0.0280(15) & 0.0297(15) & 0.0080(12) & 0.0016(13) & 0.0041(13) \\ \text { C3 } & 0.0295(18) & 0.0159(13) & 0.0300(15) & 0.0026(12) & 0.0037(13) & 0.0018(12) \\ \text { C4 } & 0.0200(15) & 0.0188(13) & 0.0146(12) & -0.0040(11) & 0.0027(11) & -0.0026(11) \\ \text { C5 } & 0.0180(15) & 0.0214(14) & 0.0261(14) & 0.0030(12) & -0.0039(12) & 0.0027(12) \\ \text { C6 } & 0.0186(16) & 0.0177(13) & 0.0363(16) & -0.0016(12) & -0.0005(13) & -0.0016(12) \\ \text { C11 } & 0.0315(4) & 0.0200(3) & 0.0212(3) & 0.0009(3) & 0.0009(3) & 0.0032(3)\end{array}$

Geometric parameters $\left(A,{ }^{\circ}\right)$

\begin{tabular}{|c|c|c|c|}
\hline As1-O11 & $1.688(2)$ & $\mathrm{C} 1-\mathrm{C} 2$ & $1.390(4)$ \\
\hline As1-O12 & $1.648(2)$ & $\mathrm{C} 1-\mathrm{C} 6$ & $1.380(4)$ \\
\hline As $1-\mathrm{O} 13$ & $1.701(2)$ & $\mathrm{C} 2-\mathrm{C} 3$ & $1.377(4)$ \\
\hline $\mathrm{As} 1-\mathrm{C} 1$ & $1.891(3)$ & $\mathrm{C} 3-\mathrm{C} 4$ & $1.374(4)$ \\
\hline $\mathrm{O} 11-\mathrm{H} 11$ & $0.88(2)$ & $\mathrm{C} 4-\mathrm{C} 5$ & $1.386(3)$ \\
\hline $\mathrm{O} 13-\mathrm{H} 13$ & $0.87(3)$ & $\mathrm{C} 5-\mathrm{C} 6$ & $1.379(4)$ \\
\hline $\mathrm{N} 4-\mathrm{C} 4$ & $1.456(4)$ & $\mathrm{C} 2-\mathrm{H} 2$ & 0.9500 \\
\hline $\mathrm{N} 4-\mathrm{H} 41$ & $0.87(2)$ & $\mathrm{C} 3-\mathrm{H} 3$ & 0.9500 \\
\hline $\mathrm{N} 4-\mathrm{H} 42$ & $0.87(2)$ & $\mathrm{C} 5-\mathrm{H} 5$ & 0.9500 \\
\hline $\mathrm{N} 4-\mathrm{H} 43$ & $0.87(2)$ & $\mathrm{C} 6-\mathrm{H} 6$ & 0.9500 \\
\hline $\mathrm{O} 11$-As1-O12 & $112.68(11)$ & $\mathrm{C} 2-\mathrm{C} 1-\mathrm{C} 6$ & $120.9(3)$ \\
\hline $\mathrm{O} 11-\mathrm{As} 1-\mathrm{O} 13$ & $108.54(11)$ & $\mathrm{C} 1-\mathrm{C} 2-\mathrm{C} 3$ & $119.4(3)$ \\
\hline $\mathrm{O} 11-\mathrm{As} 1-\mathrm{C} 1$ & $107.71(11)$ & $\mathrm{C} 2-\mathrm{C} 3-\mathrm{C} 4$ & $119.1(3)$ \\
\hline $\mathrm{O} 12-\mathrm{As} 1-\mathrm{O} 13$ & $111.29(11)$ & $\mathrm{N} 4-\mathrm{C} 4-\mathrm{C} 3$ & $119.6(2)$ \\
\hline $\mathrm{O} 12-\mathrm{As} 1-\mathrm{C} 1$ & $113.18(11)$ & $\mathrm{N} 4-\mathrm{C} 4-\mathrm{C} 5$ & $118.2(2)$ \\
\hline $\mathrm{O} 13-\mathrm{As} 1-\mathrm{C} 1$ & $102.89(12)$ & $\mathrm{C} 3-\mathrm{C} 4-\mathrm{C} 5$ & $122.2(3)$ \\
\hline As1-O11-H11 & $117(2)$ & $\mathrm{C} 4-\mathrm{C} 5-\mathrm{C} 6$ & $118.4(3)$ \\
\hline As1-O13-H13 & $112(2)$ & $\mathrm{C} 1-\mathrm{C} 6-\mathrm{C} 5$ & $120.0(3)$ \\
\hline $\mathrm{H} 42-\mathrm{N} 4-\mathrm{H} 43$ & $113(3)$ & $\mathrm{C} 1-\mathrm{C} 2-\mathrm{H} 2$ & 120.00 \\
\hline $\mathrm{H} 41-\mathrm{N} 4-\mathrm{H} 42$ & $103(2)$ & $\mathrm{C} 3-\mathrm{C} 2-\mathrm{H} 2$ & 120.00 \\
\hline $\mathrm{H} 41-\mathrm{N} 4-\mathrm{H} 43$ & $103(2)$ & $\mathrm{C} 2-\mathrm{C} 3-\mathrm{H} 3$ & 120.00 \\
\hline $\mathrm{C} 4-\mathrm{N} 4-\mathrm{H} 41$ & $114(2)$ & $\mathrm{C} 4-\mathrm{C} 3-\mathrm{H} 3$ & 120.00 \\
\hline $\mathrm{C} 4-\mathrm{N} 4-\mathrm{H} 42$ & $111.6(18)$ & $\mathrm{C} 4-\mathrm{C} 5-\mathrm{H} 5$ & 121.00 \\
\hline $\mathrm{C} 4-\mathrm{N} 4-\mathrm{H} 43$ & $111.3(15)$ & $\mathrm{C} 6-\mathrm{C} 5-\mathrm{H} 5$ & 121.00 \\
\hline $\mathrm{As} 1-\mathrm{C} 1-\mathrm{C} 2$ & $120.4(2)$ & $\mathrm{C} 1-\mathrm{C} 6-\mathrm{H} 6$ & 120.00 \\
\hline $\mathrm{As} 1-\mathrm{C} 1-\mathrm{C} 6$ & $118.7(2)$ & $\mathrm{C} 5-\mathrm{C} 6-\mathrm{H} 6$ & 120.00 \\
\hline $\mathrm{O} 11-\mathrm{As} 1-\mathrm{C} 1-\mathrm{C} 2$ & $-22.9(2)$ & $\mathrm{As} 1-\mathrm{C} 1-\mathrm{C} 6-\mathrm{C} 5$ & $178.4(2)$ \\
\hline $\mathrm{O} 11-\mathrm{As} 1-\mathrm{C} 1-\mathrm{C} 6$ & $159.1(2)$ & $\mathrm{C} 2-\mathrm{C} 1-\mathrm{C} 6-\mathrm{C} 5$ & $0.4(4)$ \\
\hline $\mathrm{O} 12-\mathrm{As} 1-\mathrm{C} 1-\mathrm{C} 2$ & $102.3(2)$ & $\mathrm{C} 1-\mathrm{C} 2-\mathrm{C} 3-\mathrm{C} 4$ & $1.2(4)$ \\
\hline $\mathrm{O} 12-\mathrm{As} 1-\mathrm{C} 1-\mathrm{C} 6$ & $-75.7(2)$ & $\mathrm{C} 2-\mathrm{C} 3-\mathrm{C} 4-\mathrm{N} 4$ & $-179.0(3)$ \\
\hline $\mathrm{O} 13-\mathrm{As} 1-\mathrm{C} 1-\mathrm{C} 2$ & $-137.5(2)$ & $\mathrm{C} 2-\mathrm{C} 3-\mathrm{C} 4-\mathrm{C} 5$ & $-0.5(4)$ \\
\hline $\mathrm{O} 13-\mathrm{As} 1-\mathrm{C} 1-\mathrm{C} 6$ & $44.5(2)$ & $\mathrm{N} 4-\mathrm{C} 4-\mathrm{C} 5-\mathrm{C} 6$ & $178.3(3)$ \\
\hline $\mathrm{As} 1-\mathrm{C} 1-\mathrm{C} 2-\mathrm{C} 3$ & $-179.1(2)$ & $\mathrm{C} 3-\mathrm{C} 4-\mathrm{C} 5-\mathrm{C} 6$ & $-0.3(4)$ \\
\hline $\mathrm{C} 6-\mathrm{C} 1-\mathrm{C} 2-\mathrm{C} 3$ & $-1.2(4)$ & $\mathrm{C} 4-\mathrm{C} 5-\mathrm{C} 6-\mathrm{C} 1$ & $0.3(4)$ \\
\hline
\end{tabular}


Hydrogen-bond geometry $\left(\AA,{ }^{\circ}\right)$

\begin{tabular}{lllll}
\hline$D-\mathrm{H} \cdots A$ & $D-\mathrm{H}$ & $\mathrm{H} \cdots A$ & $D \cdots A$ & $D-\mathrm{H} \cdots A$ \\
\hline $\mathrm{O} 11-\mathrm{H} 11 \cdots \mathrm{O} 12^{\mathrm{i}}$ & $0.88(2)$ & $1.68(2)$ & $2.563(3)$ & $178(5)$ \\
$\mathrm{O} 13-\mathrm{H} 13 \cdots \mathrm{O} 12^{\mathrm{ii}}$ & $0.87(3)$ & $1.73(3)$ & $2.582(3)$ & $167(4)$ \\
$\mathrm{N} 4-\mathrm{H} 41 \cdots \mathrm{C} 11^{\mathrm{iii}}$ & $0.87(2)$ & $2.29(2)$ & $3.073(2)$ & $151(3)$ \\
$\mathrm{N} 4-\mathrm{H} 42 \cdots \mathrm{C} 11$ & $0.87(2)$ & $2.27(2)$ & $3.091(2)$ & $158(2)$ \\
$\mathrm{N} 4-\mathrm{H} 43 \cdots \mathrm{C} 11^{\mathrm{i}}$ & $0.87(2)$ & $2.30(2)$ & $3.160(3)$ & $170(2)$
\end{tabular}

Symmetry codes: (i) $-x+1,-y+1,-z+1$; (ii) $x,-y+3 / 2, z+1 / 2$; (iii) $x,-y-1 / 2, z-1 / 2$; (iv) $-x, y+1 / 2,-z+1 / 2$.

(II) Hexaaquacopper(II) bis(4-arsonoanilinium) disulfate dihydrate

Crystal data

$\left(\mathrm{C}_{6} \mathrm{H}_{9} \mathrm{AsNO}_{3}\right)_{2}\left[\mathrm{Cu}\left(\mathrm{H}_{2} \mathrm{O}\right)_{6}\right]\left(\mathrm{SO}_{4}\right)_{2} \cdot 2 \mathrm{H}_{2} \mathrm{O}$

$F(000)=846$

$M_{r}=835.92$

$D_{\mathrm{x}}=1.915 \mathrm{Mg} \mathrm{m}^{-3}$

Monoclinic, $P 2{ }_{1} / c$

Mo $K \alpha$ radiation, $\lambda=0.71073 \AA$

Hall symbol: -P 2ybc

Cell parameters from 2421 reflections

$a=15.0784(6) \AA$

$\theta=3.8-29.0^{\circ}$

$b=11.2302(4) \AA$

$\mu=3.26 \mathrm{~mm}^{-1}$

$c=8.6756(4) \AA$

$T=200 \mathrm{~K}$

$\beta=99.305(4)^{\circ}$

Plate, colourless

$V=1449.74(10) \AA^{3}$

$0.30 \times 0.25 \times 0.08 \mathrm{~mm}$

$Z=2$

\section{Data collection}

Oxford Diffraction Gemini-S CCD-detector diffractometer

6196 measured reflections

2846 independent reflections

Radiation source: Enhance (Mo) X-ray source

2518 reflections with $I>2 \sigma(I)$

Graphite monochromator

$R_{\text {int }}=0.026$

Detector resolution: 16.077 pixels $\mathrm{mm}^{-1}$

$\omega$ scans

Absorption correction: multi-scan

(CrysAlis PRO; Rigaku OD, 2015)

$\theta_{\max }=26.0^{\circ}, \theta_{\min }=3.3^{\circ}$

$h=-18 \rightarrow 17$

$k=-13 \rightarrow 12$

$l=-9 \rightarrow 10$

$T_{\min }=0.670, T_{\max }=0.980$

\section{Refinement}

Refinement on $F^{2}$

Least-squares matrix: full

$R\left[F^{2}>2 \sigma\left(F^{2}\right)\right]=0.027$

$w R\left(F^{2}\right)=0.066$

$S=1.05$

2846 reflections

226 parameters

13 restraints

Primary atom site location: structure-invariant direct methods

Secondary atom site location: difference Fourier map

Hydrogen site location: inferred from neighbouring sites

$\mathrm{H}$ atoms treated by a mixture of independent and constrained refinement

$w=1 /\left[\sigma^{2}\left(F_{\mathrm{o}}^{2}\right)+(0.0274 P)^{2}+0.3694 P\right]$

where $P=\left(F_{\mathrm{o}}^{2}+2 F_{\mathrm{c}}^{2}\right) / 3$

$(\Delta / \sigma)_{\max }<0.001$

$\Delta \rho_{\max }=0.36$ e $\AA^{-3}$

$\Delta \rho_{\min }=-0.51$ e $\AA^{-3}$

Special details

Geometry. Bond distances, angles etc. have been calculated using the rounded fractional coordinates. All su's are estimated from the variances of the (full) variance-covariance matrix. The cell esds are taken into account in the estimation of distances, angles and torsion angles 
Refinement. Refinement of $\mathrm{F}^{2}$ against ALL reflections. The weighted R-factor $\mathrm{wR}$ and goodness of fit $\mathrm{S}$ are based on $\mathrm{F}^{2}$, conventional R-factors $R$ are based on $F$, with $F$ set to zero for negative $F^{2}$. The threshold expression of $F^{2}>2 \operatorname{sigma}\left(F^{2}\right)$ is used only for calculating R-factors(gt) etc. and is not relevant to the choice of reflections for refinement. R-factors based on $\mathrm{F}^{2}$ are statistically about twice as large as those based on F, and R- factors based on ALL data will be even larger.

Fractional atomic coordinates and isotropic or equivalent isotropic displacement parameters $\left(\AA^{2}\right)$

\begin{tabular}{|c|c|c|c|c|}
\hline & $x$ & $y$ & $z$ & $U_{\text {iso }} * / U_{\text {eq }}$ \\
\hline As1 & $0.33980(2)$ & $0.10571(2)$ & $0.24157(3)$ & $0.0172(1)$ \\
\hline O11 & $0.36399(14)$ & $0.0443(2)$ & $0.4232(2)$ & $0.0276(7)$ \\
\hline $\mathrm{O} 12$ & $0.26786(13)$ & $0.02573(18)$ & $0.1225(2)$ & $0.0249(6)$ \\
\hline $\mathrm{O} 13$ & $0.30451(14)$ & $0.24789(18)$ & $0.2623(3)$ & $0.0305(7)$ \\
\hline N4 & $0.71564(17)$ & $0.1526(2)$ & $0.0761(3)$ & $0.0174(7)$ \\
\hline $\mathrm{C} 1$ & $0.45558(19)$ & $0.1223(2)$ & $0.1863(3)$ & $0.0165(8)$ \\
\hline $\mathrm{C} 2$ & $0.4777(2)$ & $0.2222(2)$ & $0.1063(3)$ & $0.0205(8)$ \\
\hline $\mathrm{C} 3$ & $0.5634(2)$ & $0.2323(2)$ & $0.0701(3)$ & $0.0213(9)$ \\
\hline $\mathrm{C} 4$ & $0.62545(18)$ & $0.1425(2)$ & $0.1130(3)$ & $0.0158(8)$ \\
\hline $\mathrm{C} 5$ & $0.6026(2)$ & $0.0410(2)$ & $0.1881(3)$ & $0.0218(9)$ \\
\hline C6 & $0.5178(2)$ & $0.0313(3)$ & $0.2253(3)$ & $0.0222(9)$ \\
\hline $\mathrm{Cu} 1$ & 0.00000 & 0.00000 & 0.00000 & $0.0135(1)$ \\
\hline $\mathrm{O} 1 \mathrm{~W}$ & $0.01471(14)$ & $0.10426(18)$ & $0.2269(2)$ & $0.0210(6)$ \\
\hline $\mathrm{O} 2 \mathrm{~W}$ & $0.10719(14)$ & $0.0857(2)$ & $-0.0346(2)$ & $0.0246(7)$ \\
\hline $\mathrm{O} 3 \mathrm{~W}$ & $-0.07864(16)$ & $0.13263(18)$ & $-0.1006(2)$ & $0.0251(7)$ \\
\hline S1 & $0.83825(5)$ & $0.41681(6)$ & $-0.01779(7)$ & $0.0152(2)$ \\
\hline $\mathrm{O} 1$ & 0.89949 (14) & 0.33415 (17) & $0.0779(2)$ & $0.0255(7)$ \\
\hline $\mathrm{O} 2$ & $0.85590(14)$ & $0.53998(16)$ & $0.0346(2)$ & $0.0229(6)$ \\
\hline $\mathrm{O} 3$ & $0.74402(14)$ & $0.38634(16)$ & $-0.0044(2)$ & $0.0222(6)$ \\
\hline $\mathrm{O} 4$ & $0.84847(14)$ & $0.40444(18)$ & $-0.1831(2)$ & $0.0232(6)$ \\
\hline $\mathrm{O} 4 \mathrm{~W}$ & $0.13231(15)$ & $0.30042(17)$ & $0.2021(2)$ & $0.0217(7)$ \\
\hline $\mathrm{H} 2$ & 0.43450 & 0.28290 & 0.07660 & $0.0250^{*}$ \\
\hline H3 & 0.57970 & 0.30060 & 0.01620 & $0.0260 *$ \\
\hline H5 & 0.64520 & -0.02130 & 0.21360 & $0.0260^{*}$ \\
\hline H6 & 0.50160 & -0.03770 & 0.27770 & $0.0270^{*}$ \\
\hline H11 & $0.3229(18)$ & $0.001(2)$ & $0.445(4)$ & $0.0330 *$ \\
\hline H13 & $0.2483(13)$ & $0.260(3)$ & $0.246(4)$ & $0.0330 *$ \\
\hline $\mathrm{H} 41$ & $0.7543(18)$ & $0.137(3)$ & $0.163(3)$ & $0.0270^{*}$ \\
\hline $\mathrm{H} 42$ & $0.724(2)$ & $0.2267(18)$ & 0.044 (3) & $0.0270^{*}$ \\
\hline H43 & $0.720(2)$ & $0.102(2)$ & $-0.002(3)$ & $0.0270^{*}$ \\
\hline H11W & $-0.0329(16)$ & $0.105(3)$ & $0.263(4)$ & $0.0330 *$ \\
\hline $\mathrm{H} 12 \mathrm{~W}$ & 0.0537 (19) & $0.082(3)$ & $0.296(3)$ & $0.0330^{*}$ \\
\hline $\mathrm{H} 21 \mathrm{~W}$ & $0.110(2)$ & $0.116(3)$ & $-0.123(3)$ & $0.0330^{*}$ \\
\hline $\mathrm{H} 22 \mathrm{~W}$ & $0.155(2)$ & $0.063(3)$ & $0.018(3)$ & $0.0330 *$ \\
\hline H31W & $-0.073(2)$ & $0.195(2)$ & $-0.050(3)$ & $0.0330 *$ \\
\hline $\mathrm{H} 32 \mathrm{~W}$ & $-0.084(2)$ & $0.146(3)$ & $-0.197(2)$ & $0.0330 *$ \\
\hline $\mathrm{H} 41 \mathrm{~W}$ & $0.0939(18)$ & $0.249(2)$ & $0.182(4)$ & $0.0330^{*}$ \\
\hline $\mathrm{H} 42 \mathrm{~W}$ & $0.126(2)$ & $0.343(3)$ & $0.125(3)$ & $0.0330^{*}$ \\
\hline
\end{tabular}


Atomic displacement parameters $\left(\AA^{2}\right)$

\begin{tabular}{lllllll}
\hline & $U^{11}$ & $U^{22}$ & $U^{33}$ & $U^{12}$ & $U^{13}$ & $U^{23}$ \\
\hline As1 & $0.0116(2)$ & $0.0185(2)$ & $0.0209(2)$ & $-0.0023(1)$ & $0.0008(1)$ & $-0.0012(1)$ \\
O11 & $0.0194(12)$ & $0.0386(13)$ & $0.0240(11)$ & $-0.0124(10)$ & $0.0014(9)$ & $0.0042(10)$ \\
O12 & $0.0132(11)$ & $0.0298(11)$ & $0.0300(11)$ & $-0.0017(9)$ & $-0.0012(9)$ & $-0.0078(9)$ \\
O13 & $0.0149(11)$ & $0.0217(11)$ & $0.0546(15)$ & $0.0006(10)$ & $0.0050(11)$ & $-0.0056(10)$ \\
N4 & $0.0141(13)$ & $0.0190(12)$ & $0.0186(12)$ & $0.0008(11)$ & $0.0010(10)$ & $0.0005(10)$ \\
C1 & $0.0126(14)$ & $0.0174(14)$ & $0.0185(14)$ & $-0.0032(11)$ & $-0.0009(12)$ & $-0.0011(11)$ \\
C2 & $0.0153(15)$ & $0.0178(14)$ & $0.0275(15)$ & $0.0040(12)$ & $0.0012(12)$ & $0.0040(12)$ \\
C3 & $0.0205(16)$ & $0.0170(14)$ & $0.0259(15)$ & $-0.0008(12)$ & $0.0021(13)$ & $0.0075(12)$ \\
C4 & $0.0115(14)$ & $0.0209(14)$ & $0.0138(13)$ & $-0.0037(12)$ & $-0.0016(11)$ & $-0.0017(11)$ \\
C5 & $0.0172(16)$ & $0.0189(14)$ & $0.0282(16)$ & $0.0049(12)$ & $0.0003(13)$ & $0.0061(12)$ \\
C6 & $0.0212(17)$ & $0.0186(14)$ & $0.0261(16)$ & $-0.0037(12)$ & $0.0021(13)$ & $0.0057(12)$ \\
Cu1 & $0.0118(2)$ & $0.0143(2)$ & $0.0142(2)$ & $0.0003(2)$ & $0.0012(2)$ & $0.0011(2)$ \\
O1W & $0.0153(11)$ & $0.0313(12)$ & $0.0162(10)$ & $0.0020(10)$ & $0.0017(8)$ & $0.0031(9)$ \\
O2W & $0.0157(11)$ & $0.0363(13)$ & $0.0212(11)$ & $-0.0046(10)$ & $0.0013(9)$ & $0.0084(9)$ \\
O3W & $0.0355(14)$ & $0.0204(11)$ & $0.0165(10)$ & $0.0043(10)$ & $-0.0043(10)$ & $-0.0003(9)$ \\
S1 & $0.0142(4)$ & $0.0175(3)$ & $0.0140(3)$ & $-0.0002(3)$ & $0.0022(3)$ & $-0.0002(3)$ \\
O1 & $0.0300(13)$ & $0.0258(11)$ & $0.0191(10)$ & $0.0114(10)$ & $-0.0010(9)$ & $0.0011(9)$ \\
O2 & $0.0261(12)$ & $0.0175(10)$ & $0.0227(10)$ & $-0.0056(9)$ & $-0.0028(9)$ & $-0.0019(8)$ \\
O3 & $0.0172(11)$ & $0.0192(10)$ & $0.0321(12)$ & $-0.0013(9)$ & $0.0099(9)$ & $-0.0017(8)$ \\
O4 & $0.0169(11)$ & $0.0391(12)$ & $0.0138(10)$ & $-0.0023(9)$ & $0.0027(8)$ & $-0.0027(8)$ \\
O4W & $0.0212(12)$ & $0.0193(11)$ & $0.0239(11)$ & $-0.0019(9)$ & $0.0012(9)$ & $-0.0001(9)$ \\
& & & & & & \\
\hline & & & & & &
\end{tabular}

Geometric parameters $\left(\AA,{ }^{\circ}\right)$

\begin{tabular}{llll}
\hline $\mathrm{Cu} 1-\mathrm{O} 3 \mathrm{~W}$ & $2.013(2)$ & $\mathrm{O} 2 \mathrm{~W}-\mathrm{H} 21 \mathrm{~W}$ & $0.85(3)$ \\
$\mathrm{Cu} 1-\mathrm{O} 1 \mathrm{~W}$ & $2.2702(18)$ & $\mathrm{O} 3 \mathrm{~W}-\mathrm{H} 31 \mathrm{~W}$ & $0.82(2)$ \\
$\mathrm{Cu} 1-\mathrm{O} 2 \mathrm{~W}$ & $1.946(2)$ & $\mathrm{O} 3 \mathrm{~W}-\mathrm{H} 32 \mathrm{~W}$ & $0.841(18)$ \\
$\mathrm{Cu} 1-\mathrm{O} 3 \mathrm{~W}^{\mathrm{i}}$ & $2.013(2)$ & $\mathrm{O} 4 \mathrm{~W}-\mathrm{H} 42 \mathrm{~W}$ & $0.82(3)$ \\
$\mathrm{Cu} 1-\mathrm{O} 1 \mathrm{~W}^{\mathrm{i}}$ & $2.2702(18)$ & $\mathrm{O} 4 \mathrm{~W}-\mathrm{H} 41 \mathrm{~W}$ & $0.82(3)$ \\
$\mathrm{Cu} 1-\mathrm{O} 2 \mathrm{~W}^{\mathrm{i}}$ & $1.946(2)$ & $\mathrm{N} 4-\mathrm{C} 4$ & $1.451(4)$ \\
$\mathrm{As} 1-\mathrm{O} 11$ & $1.7046(18)$ & $\mathrm{N} 4-\mathrm{H} 42$ & $0.89(2)$ \\
$\mathrm{As} 1-\mathrm{O} 12$ & $1.6395(19)$ & $\mathrm{N} 4-\mathrm{H} 43$ & $0.90(2)$ \\
$\mathrm{As} 1-\mathrm{O} 13$ & $1.702(2)$ & $\mathrm{N} 4-\mathrm{H} 41$ & $0.89(3)$ \\
$\mathrm{As} 1-\mathrm{C} 1$ & $1.893(3)$ & $\mathrm{C} 1-\mathrm{C} 2$ & $1.388(3)$ \\
$\mathrm{S} 1-\mathrm{O} 4$ & $1.4736(19)$ & $\mathrm{C} 1-\mathrm{C} 6$ & $1.392(4)$ \\
$\mathrm{S} 1-\mathrm{O} 2$ & $1.4668(19)$ & $\mathrm{C} 2-\mathrm{C} 3$ & $1.383(4)$ \\
$\mathrm{S} 1-\mathrm{O} 3$ & $1.484(2)$ & $\mathrm{C} 3-\mathrm{C} 4$ & $1.385(4)$ \\
$\mathrm{S} 1-\mathrm{O} 1$ & $1.468(2)$ & $\mathrm{C} 4-\mathrm{C} 5$ & $1.384(3)$ \\
$\mathrm{O} 11-\mathrm{H} 11$ & $\mathrm{C} 5-\mathrm{C} 6$ & 0.9500 \\
$\mathrm{O} 13-\mathrm{H} 13$ & $0.83(3)$ & $\mathrm{C} 2-\mathrm{H} 2$ & 0.9500 \\
$\mathrm{O} 1 \mathrm{~W}-\mathrm{H} 12 \mathrm{~W}$ & $0.85(2)$ & $\mathrm{C} 3-\mathrm{H} 3$ & 0.9500 \\
$\mathrm{O} 1 \mathrm{~W}-\mathrm{H} 11 \mathrm{~W}$ & $0.81(3)$ & $\mathrm{C} 5-\mathrm{H} 5$ & 0.9500 \\
$\mathrm{O} 2 \mathrm{~W}-\mathrm{H} 22 \mathrm{~W}$ & $0.83(3)$ & $\mathrm{C}-\mathrm{H} 6$ & $111(3)$ \\
$\mathrm{O} 11-\mathrm{As} 1-\mathrm{O} 12$ & $0.83(3)$ & $\mathrm{H} 31 \mathrm{~W}-\mathrm{O} 3 \mathrm{~W}-\mathrm{H} 32 \mathrm{~W}$ &
\end{tabular}




\begin{tabular}{|c|c|c|c|}
\hline $\mathrm{O} 11-\mathrm{As} 1-\mathrm{O} 13$ & $107.80(11)$ & $\mathrm{Cu} 1-\mathrm{O} 3 \mathrm{~W}-\mathrm{H} 32 \mathrm{~W}$ & $121(2)$ \\
\hline $\mathrm{O} 11-\mathrm{As} 1-\mathrm{C} 1$ & $101.87(11)$ & $\mathrm{Cu} 1-\mathrm{O} 3 \mathrm{~W}-\mathrm{H} 31 \mathrm{~W}$ & $113.3(19)$ \\
\hline $\mathrm{O} 12-\mathrm{As} 1-\mathrm{O} 13$ & $113.22(11)$ & $\mathrm{H} 41 \mathrm{~W}-\mathrm{O} 4 \mathrm{~W}-\mathrm{H} 42 \mathrm{~W}$ & $105(3)$ \\
\hline $\mathrm{O} 12-\mathrm{As} 1-\mathrm{C} 1$ & $115.95(10)$ & $\mathrm{H} 42-\mathrm{N} 4-\mathrm{H} 43$ & $109(2)$ \\
\hline $\mathrm{O} 13-\mathrm{As} 1-\mathrm{C} 1$ & $104.56(10)$ & $\mathrm{H} 41-\mathrm{N} 4-\mathrm{H} 42$ & $110(3)$ \\
\hline $\mathrm{O} 2 \mathrm{~W}-\mathrm{Cu} 1-\mathrm{O} 3 \mathrm{~W}$ & $90.74(9)$ & $\mathrm{H} 41-\mathrm{N} 4-\mathrm{H} 43$ & $113(3)$ \\
\hline $\mathrm{O} 1 \mathrm{~W}^{\mathrm{i}}-\mathrm{Cu} 1-\mathrm{O} 2 \mathrm{~W}$ & $95.08(8)$ & $\mathrm{C} 4-\mathrm{N} 4-\mathrm{H} 41$ & $107.8(17)$ \\
\hline $\mathrm{O} 2 \mathrm{~W}-\mathrm{Cu} 1-\mathrm{O} 2 \mathrm{~W}^{\mathrm{i}}$ & 180.00 & $\mathrm{C} 4-\mathrm{N} 4-\mathrm{H} 42$ & $109.0(19)$ \\
\hline $\mathrm{O} 2 \mathrm{~W}-\mathrm{Cu} 1-\mathrm{O} 3 \mathrm{~W}^{\mathrm{i}}$ & $89.26(9)$ & $\mathrm{C} 4-\mathrm{N} 4-\mathrm{H} 43$ & $107.7(19)$ \\
\hline $\mathrm{O} 1 \mathrm{~W}^{\mathrm{i}}-\mathrm{Cu} 1-\mathrm{O} 3 \mathrm{~W}$ & $92.15(7)$ & As1-C1-C2 & $120.8(2)$ \\
\hline $\mathrm{O} 3 \mathrm{~W}-\mathrm{Cu} 1-\mathrm{O} 3 \mathrm{~W}^{\mathrm{i}}$ & 180.00 & $\mathrm{As} 1-\mathrm{C} 1-\mathrm{C} 6$ & $118.6(2)$ \\
\hline $\mathrm{O} 1 \mathrm{~W}-\mathrm{Cu} 1-\mathrm{O} 1 \mathrm{~W}^{\mathrm{i}}$ & 180.00 & $\mathrm{C} 2-\mathrm{C} 1-\mathrm{C} 6$ & $120.5(3)$ \\
\hline $\mathrm{O} 1 \mathrm{~W}-\mathrm{Cu} 1-\mathrm{O} 2 \mathrm{~W}$ & $84.92(8)$ & $\mathrm{C} 1-\mathrm{C} 2-\mathrm{C} 3$ & $119.3(2)$ \\
\hline $\mathrm{O} 1 \mathrm{~W}-\mathrm{Cu} 1-\mathrm{O} 3 \mathrm{~W}$ & $87.85(7)$ & $\mathrm{C} 2-\mathrm{C} 3-\mathrm{C} 4$ & $119.7(2)$ \\
\hline $\mathrm{O} 3-\mathrm{S} 1-\mathrm{O} 4$ & $107.85(11)$ & $\mathrm{N} 4-\mathrm{C} 4-\mathrm{C} 3$ & $120.0(2)$ \\
\hline $\mathrm{O} 2-\mathrm{S} 1-\mathrm{O} 4$ & $110.38(11)$ & $\mathrm{N} 4-\mathrm{C} 4-\mathrm{C} 5$ & $118.8(2)$ \\
\hline $\mathrm{O} 1-\mathrm{S} 1-\mathrm{O} 3$ & $109.42(11)$ & $\mathrm{C} 3-\mathrm{C} 4-\mathrm{C} 5$ & $121.2(3)$ \\
\hline $\mathrm{O} 1-\mathrm{S} 1-\mathrm{O} 4$ & $109.60(12)$ & $\mathrm{C} 4-\mathrm{C} 5-\mathrm{C} 6$ & $119.2(3)$ \\
\hline $\mathrm{O} 1-\mathrm{S} 1-\mathrm{O} 2$ & $110.79(11)$ & $\mathrm{C} 1-\mathrm{C} 6-\mathrm{C} 5$ & $120.1(3)$ \\
\hline $\mathrm{O} 2-\mathrm{S} 1-\mathrm{O} 3$ & $108.74(12)$ & $\mathrm{C} 1-\mathrm{C} 2-\mathrm{H} 2$ & 120.00 \\
\hline As1-O11-H11 & $113(2)$ & $\mathrm{C} 3-\mathrm{C} 2-\mathrm{H} 2$ & 120.00 \\
\hline As1-O13-H13 & $117(2)$ & $\mathrm{C} 2-\mathrm{C} 3-\mathrm{H} 3$ & 120.00 \\
\hline $\mathrm{H} 11 \mathrm{~W}-\mathrm{O} 1 \mathrm{~W}-\mathrm{H} 12 \mathrm{~W}$ & $107(3)$ & $\mathrm{C} 4-\mathrm{C} 3-\mathrm{H} 3$ & 120.00 \\
\hline $\mathrm{Cu} 1-\mathrm{O} 1 \mathrm{~W}-\mathrm{H} 12 \mathrm{~W}$ & $116(2)$ & $\mathrm{C} 4-\mathrm{C} 5-\mathrm{H} 5$ & 120.00 \\
\hline $\mathrm{Cu} 1-\mathrm{O} 1 \mathrm{~W}-\mathrm{H} 11 \mathrm{~W}$ & $111(2)$ & $\mathrm{C} 6-\mathrm{C} 5-\mathrm{H} 5$ & 120.00 \\
\hline $\mathrm{H} 21 \mathrm{~W}-\mathrm{O} 2 \mathrm{~W}-\mathrm{H} 22 \mathrm{~W}$ & $117(3)$ & $\mathrm{C} 1-\mathrm{C} 6-\mathrm{H} 6$ & 120.00 \\
\hline $\mathrm{Cu} 1-\mathrm{O} 2 \mathrm{~W}-\mathrm{H} 22 \mathrm{~W}$ & $116(2)$ & $\mathrm{C} 5-\mathrm{C} 6-\mathrm{H} 6$ & 120.00 \\
\hline $\mathrm{Cu} 1-\mathrm{O} 2 \mathrm{~W}-\mathrm{H} 21 \mathrm{~W}$ & $120(2)$ & & \\
\hline $\mathrm{O} 11-\mathrm{As} 1-\mathrm{C} 1-\mathrm{C} 2$ & $-140.8(2)$ & As $1-\mathrm{C} 1-\mathrm{C} 6-\mathrm{C} 5$ & $-179.4(2)$ \\
\hline $\mathrm{O} 11-\mathrm{As} 1-\mathrm{C} 1-\mathrm{C} 6$ & $40.3(2)$ & $\mathrm{C} 2-\mathrm{C} 1-\mathrm{C} 6-\mathrm{C} 5$ & $1.6(4)$ \\
\hline $\mathrm{O} 12-\mathrm{As} 1-\mathrm{C} 1-\mathrm{C} 2$ & $96.8(2)$ & $\mathrm{C} 1-\mathrm{C} 2-\mathrm{C} 3-\mathrm{C} 4$ & $0.5(4)$ \\
\hline $\mathrm{O} 12-\mathrm{As} 1-\mathrm{C} 1-\mathrm{C} 6$ & $-82.2(2)$ & $\mathrm{C} 2-\mathrm{C} 3-\mathrm{C} 4-\mathrm{N} 4$ & $-179.7(2)$ \\
\hline $\mathrm{O} 13-\mathrm{As} 1-\mathrm{C} 1-\mathrm{C} 2$ & $-28.6(2)$ & $\mathrm{C} 2-\mathrm{C} 3-\mathrm{C} 4-\mathrm{C} 5$ & $1.7(4)$ \\
\hline $\mathrm{O} 13-\mathrm{As} 1-\mathrm{C} 1-\mathrm{C} 6$ & $152.4(2)$ & $\mathrm{N} 4-\mathrm{C} 4-\mathrm{C} 5-\mathrm{C} 6$ & $179.2(2)$ \\
\hline $\mathrm{As} 1-\mathrm{C} 1-\mathrm{C} 2-\mathrm{C} 3$ & $178.93(19)$ & $\mathrm{C} 3-\mathrm{C} 4-\mathrm{C} 5-\mathrm{C} 6$ & $-2.3(4)$ \\
\hline $\mathrm{C} 6-\mathrm{C} 1-\mathrm{C} 2-\mathrm{C} 3$ & $-2.1(4)$ & $\mathrm{C} 4-\mathrm{C} 5-\mathrm{C} 6-\mathrm{C} 1$ & $0.6(4)$ \\
\hline
\end{tabular}

Symmetry code: (i) $-x,-y,-z$.

Hydrogen-bond geometry $\left(A,{ }^{\circ}\right)$

\begin{tabular}{lllll}
\hline$D-\mathrm{H} \cdots A$ & $D-\mathrm{H}$ & $\mathrm{H} \cdots A$ & $D \cdots A$ & $D-\mathrm{H} \cdots A$ \\
\hline $\mathrm{O} 11-\mathrm{H} 11 \cdots \mathrm{O} 3{ }^{i i}$ & $0.83(3)$ & $1.76(3)$ & $2.582(3)$ & $167(3)$ \\
$\mathrm{O} 13-\mathrm{H} 13 \cdots \mathrm{O} 4 W$ & $0.85(2)$ & $1.79(2)$ & $2.631(3)$ & $174(3)$ \\
$\mathrm{O} 1 W-\mathrm{H} 11 W \cdots \mathrm{O} 4{ }^{\text {iii }}$ & $0.83(3)$ & $1.92(3)$ & $2.745(3)$ & $171(4)$ \\
$\mathrm{O} 1 W-\mathrm{H} 12 W \cdots \mathrm{O} 2^{\text {ii }}$ & $0.81(3)$ & $1.90(3)$ & $2.703(3)$ & $176(3)$ \\
$\mathrm{O} 2 W-\mathrm{H} 21 W \cdots \mathrm{O} 4 W^{\text {iv }}$ & $0.85(3)$ & $1.86(3)$ & $2.698(3)$ & $170(3)$
\end{tabular}




$\begin{array}{lllll}\mathrm{O} 2 W-\mathrm{H} 22 W \cdots \mathrm{O} 12 & 0.83(3) & 1.84(3) & 2.667(3) & 173(3) \\ \mathrm{O} 3 W-\mathrm{H} 31 W \cdots{ }^{\mathrm{v}} & 0.82(2) & 2.00(2) & 2.792(3) & 161(3) \\ \mathrm{O} 3 W-\mathrm{H} 32 W \cdots \mathrm{O} 1^{\mathrm{vi}} & 0.84(2) & 1.94(2) & 2.780(2) & 176(4) \\ \mathrm{O} 4 W-\mathrm{H} 41 W \cdots \mathrm{O} 1 W & 0.82(3) & 2.09(3) & 2.858(3) & 157(3) \\ \mathrm{O} 4 W-\mathrm{H} 42 W \cdots \mathrm{O} 2^{\mathrm{vii}} & 0.82(3) & 1.96(3) & 2.753(3) & 164(3) \\ \mathrm{N} 4-\mathrm{H} 41 \cdots \mathrm{O} 4{ }^{\mathrm{viii}} & 0.89(3) & 1.85(3) & 2.726(3) & 169(3) \\ \mathrm{N} 4-\mathrm{H} 42 \cdots \mathrm{O} 3 & 0.89(2) & 1.88(2) & 2.767(3) & 175(2) \\ \mathrm{N} 4-\mathrm{H} 43 \cdots \mathrm{O} 12^{\text {ix }} & 0.90(2) & 1.80(2) & 2.680(3) & 166(2) \\ \mathrm{C} 2-\mathrm{H} 2 \cdots \mathrm{O} 11^{\text {iv }} & 0.95 & 2.49 & 3.385(3) & 157\end{array}$

Symmetry codes: (ii) $-x+1, y-1 / 2,-z+1 / 2$; (iii) $x-1,-y+1 / 2, z+1 / 2$; (iv) $x,-y+1 / 2, z-1 / 2$; (v) $x-1, y, z$; (vi) $x-1,-y+1 / 2, z-1 / 2$; (vii) $-x+1,-y+1,-z$; (viii) $x,-y+1 / 2, z+1 / 2$; (ix) $-x+1,-y,-z$.

(III) Poly[bis(4-arsonoanilinium) [tetra- $\mu$-chlorido-cuprate(II)]]

\section{Crystal data}

$\left(\mathrm{C}_{6} \mathrm{H}_{9} \mathrm{AsNO}_{3}\right)_{2}\left[\mathrm{CuCl}_{4}\right]$

$M_{r}=641.47$

Orthorhombic, $\mathrm{Pbca}$

Hall symbol: -P $2 \mathrm{ac} 2 \mathrm{ab}$

$a=7.6315(4) \AA$

$b=7.1244(4) \AA$

$c=38.0925(15) \AA$

$V=2071.08(18) \AA^{3}$

$Z=4$

\section{Data collection}

Oxford Diffraction Gemini-S CCD-detector diffractometer

Radiation source: Enhance (Mo) X-ray source

Graphite monochromator

Detector resolution: 16.077 pixels $\mathrm{mm}^{-1}$

$\omega$ scans

Absorption correction: multi-scan

(CrysAlis PRO; Rigaku OD, 2015)

$T_{\min }=0.544, T_{\max }=0.980$

\section{Refinement}

Refinement on $F^{2}$

Least-squares matrix: full

$R\left[F^{2}>2 \sigma\left(F^{2}\right)\right]=0.034$

$w R\left(F^{2}\right)=0.090$

$S=1.13$

2028 reflections

139 parameters

5 restraints

Primary atom site location: structure-invariant direct methods
$F(000)=1260$

$D_{\mathrm{x}}=2.057 \mathrm{Mg} \mathrm{m}^{-3}$

Mo $K \alpha$ radiation, $\lambda=0.71073 \AA$

Cell parameters from 1633 reflections

$\theta=3.9-29.0^{\circ}$

$\mu=4.77 \mathrm{~mm}^{-1}$

$T=200 \mathrm{~K}$

Plate, green

$0.25 \times 0.25 \times 0.04 \mathrm{~mm}$

6065 measured reflections

2028 independent reflections

1715 reflections with $I>2 \sigma(I)$

$R_{\text {int }}=0.032$

$\theta_{\max }=26.0^{\circ}, \theta_{\min }=3.2^{\circ}$

$h=-9 \rightarrow 9$

$k=-3 \rightarrow 8$

$l=-46 \rightarrow 28$
Secondary atom site location: difference Fourier map

Hydrogen site location: inferred from neighbouring sites

$\mathrm{H}$ atoms treated by a mixture of independent and constrained refinement

$w=1 /\left[\sigma^{2}\left(F_{\mathrm{o}}^{2}\right)+(0.0415 P)^{2}+0.2932 P\right]$ where $P=\left(F_{\mathrm{o}}^{2}+2 F_{\mathrm{c}}{ }^{2}\right) / 3$

$(\Delta / \sigma)_{\max }=0.001$

$\Delta \rho_{\max }=0.42 \mathrm{e} \AA^{-3}$

$\Delta \rho_{\min }=-0.57$ e $\AA^{-3}$

\section{Special details}

Geometry. Bond distances, angles etc. have been calculated using the rounded fractional coordinates. All su's are estimated from the variances of the (full) variance-covariance matrix. The cell esds are taken into account in the estimation of distances, angles and torsion angles 
Refinement. Refinement of $\mathrm{F}^{2}$ against ALL reflections. The weighted $\mathrm{R}$-factor $\mathrm{wR}$ and goodness of fit $\mathrm{S}$ are based on $\mathrm{F}^{2}$, conventional R-factors $R$ are based on $F$, with $F$ set to zero for negative $F^{2}$. The threshold expression of $F^{2}>2 \operatorname{sigma}\left(F^{2}\right)$ is used only for calculating R-factors(gt) etc. and is not relevant to the choice of reflections for refinement. R-factors based on $\mathrm{F}^{2}$ are statistically about twice as large as those based on F, and R- factors based on ALL data will be even larger.

Fractional atomic coordinates and isotropic or equivalent isotropic displacement parameters $\left(\AA^{2}\right)$

\begin{tabular}{lllll}
\hline & $x$ & $y$ & $z$ & $U_{\text {iso }}^{*} / U_{\text {eq }}$ \\
\hline Cu1 & 0.50000 & 0.50000 & 0.50000 & $0.0224(2)$ \\
C11 & $0.54832(12)$ & $0.52358(15)$ & $0.44103(2)$ & $0.0294(3)$ \\
C12 & $0.70111(12)$ & $0.73489(12)$ & $0.50945(3)$ & $0.0288(3)$ \\
As1 & $1.05548(5)$ & $0.75093(6)$ & $0.29143(1)$ & $0.0228(1)$ \\
O11 & $1.2663(3)$ & $0.8193(4)$ & $0.28480(7)$ & $0.0352(9)$ \\
O12 & $0.9644(3)$ & $0.6341(4)$ & $0.25899(6)$ & $0.0336(9)$ \\
O13 & $0.9462(4)$ & $0.9566(4)$ & $0.29820(8)$ & $0.0363(10)$ \\
N4 & $0.9665(5)$ & $0.4774(5)$ & $0.44152(9)$ & $0.0291(11)$ \\
C1 & $1.0413(4)$ & $0.6402(6)$ & $0.33687(9)$ & $0.0226(11)$ \\
C2 & $1.1575(5)$ & $0.6990(6)$ & $0.36228(9)$ & $0.0318(14)$ \\
C3 & $1.1353(5)$ & $0.6432(6)$ & $0.39646(9)$ & $0.0296(11)$ \\
C4 & $0.9985(5)$ & $0.5270(5)$ & $0.40483(10)$ & $0.0244(11)$ \\
C5 & $0.8857(5)$ & $0.4604(6)$ & $0.37931(10)$ & $0.0360(13)$ \\
C6 & $0.9080(5)$ & $0.5174(6)$ & $0.34507(10)$ & $0.0334(13)$ \\
H2 & 1.25290 & 0.77810 & 0.35610 & $0.0380^{*}$ \\
H3 & 1.21400 & 0.68470 & 0.41410 & $0.0360^{*}$ \\
H5 & 0.79390 & 0.37630 & 0.38530 & $0.0430^{*}$ \\
H6 & 0.83200 & 0.47230 & 0.32720 & $0.0400^{*}$ \\
H11 & $1.321(5)$ & $0.750(5)$ & $0.2708(11)$ & $0.0530^{*}$ \\
H13 & $0.961(6)$ & $1.033(6)$ & $0.2812(10)$ & $0.0550^{*}$ \\
H41 & $0.985(5)$ & $0.356(3)$ & $0.4438(11)$ & $0.0350^{*}$ \\
H42 & $1.046(4)$ & $0.530(6)$ & $0.4545(10)$ & $0.0350^{*}$ \\
H43 & $0.859(3)$ & $0.506(5)$ & $0.4486(10)$ & $0.0350^{*}$ \\
& & & & \\
\hline
\end{tabular}

Atomic displacement parameters $\left(\AA^{2}\right)$

\begin{tabular}{lllllll}
\hline & $U^{11}$ & $U^{22}$ & $U^{33}$ & $U^{12}$ & $U^{13}$ & $U^{23}$ \\
\hline Cu1 & $0.0255(3)$ & $0.0225(4)$ & $0.0191(3)$ & $-0.0066(3)$ & $0.0005(3)$ & $0.0006(3)$ \\
C11 & $0.0326(5)$ & $0.0355(6)$ & $0.0200(5)$ & $-0.0028(4)$ & $0.0018(4)$ & $0.0006(4)$ \\
C12 & $0.0300(5)$ & $0.0261(5)$ & $0.0302(5)$ & $-0.0094(4)$ & $-0.0015(4)$ & $-0.0001(4)$ \\
As1 & $0.0241(2)$ & $0.0295(3)$ & $0.0149(2)$ & $0.0019(2)$ & $0.0007(1)$ & $0.0009(2)$ \\
O11 & $0.0292(15)$ & $0.0446(19)$ & $0.0319(15)$ & $-0.0032(14)$ & $0.0086(12)$ & $-0.0056(14)$ \\
O12 & $0.0379(15)$ & $0.0431(19)$ & $0.0198(14)$ & $-0.0001(13)$ & $-0.0064(11)$ & $-0.0016(13)$ \\
O13 & $0.0402(16)$ & $0.0367(19)$ & $0.0321(15)$ & $0.0121(13)$ & $0.0116(13)$ & $0.0076(14)$ \\
N4 & $0.0339(18)$ & $0.033(2)$ & $0.0204(17)$ & $0.0044(16)$ & $0.0026(14)$ & $0.0052(16)$ \\
C1 & $0.0260(18)$ & $0.024(2)$ & $0.0177(18)$ & $0.0011(15)$ & $-0.0012(14)$ & $0.0035(16)$ \\
C2 & $0.033(2)$ & $0.039(3)$ & $0.0234(19)$ & $-0.0129(18)$ & $-0.0010(16)$ & $0.0047(18)$ \\
C3 & $0.033(2)$ & $0.034(2)$ & $0.0219(18)$ & $-0.0086(18)$ & $-0.0082(16)$ & $-0.0007(18)$ \\
C4 & $0.0273(19)$ & $0.025(2)$ & $0.0208(19)$ & $0.0033(16)$ & $0.0045(15)$ & $0.0024(16)$ \\
C5 & $0.036(2)$ & $0.048(3)$ & $0.0240(18)$ & $-0.020(2)$ & $-0.0017(18)$ & $0.0030(19)$
\end{tabular}




$\begin{array}{lllllll}\mathrm{C} 6 & 0.032(2) & 0.047(3) & 0.0212(18) & -0.0145(19) & -0.0070(17) & -0.0005(19)\end{array}$

Geometric parameters $\left(\AA,{ }^{\circ}\right)$

\begin{tabular}{|c|c|c|c|}
\hline $\mathrm{Cu} 1-\mathrm{Cl} 2^{\mathrm{i}}$ & $2.2990(9)$ & $\mathrm{N} 4-\mathrm{H} 41$ & $0.88(2)$ \\
\hline $\mathrm{Cu} 1-\mathrm{Cl}^{\mathrm{ii}}$ & $2.9833(9)$ & $\mathrm{N} 4-\mathrm{H} 42$ & $0.87(4)$ \\
\hline $\mathrm{Cu} 1-\mathrm{Cl1}^{\mathrm{i}}$ & $2.2826(8)$ & $\mathrm{N} 4-\mathrm{H} 43$ & $0.89(3)$ \\
\hline $\mathrm{Cu} 1-\mathrm{Cl1}$ & $2.2826(8)$ & $\mathrm{C} 1-\mathrm{C} 2$ & $1.378(5)$ \\
\hline $\mathrm{Cu} 1-\mathrm{Cl} 2$ & $2.2990(9)$ & $\mathrm{C} 1-\mathrm{C} 6$ & $1.378(5)$ \\
\hline $\mathrm{Cu} 1-\mathrm{Cl} 2^{\mathrm{iii}}$ & $2.9833(9)$ & $\mathrm{C} 2-\mathrm{C} 3$ & $1.372(5)$ \\
\hline As $1-\mathrm{O} 12$ & $1.644(2)$ & $\mathrm{C} 3-\mathrm{C} 4$ & $1.370(5)$ \\
\hline As1-O13 & $1.706(3)$ & $\mathrm{C} 4-\mathrm{C} 5$ & $1.383(5)$ \\
\hline As $1-\mathrm{C} 1$ & $1.905(4)$ & $\mathrm{C} 5-\mathrm{C} 6$ & $1.377(5)$ \\
\hline As1-O11 & $1.700(2)$ & $\mathrm{C} 2-\mathrm{H} 2$ & 0.9500 \\
\hline $\mathrm{O} 11-\mathrm{H} 11$ & $0.84(4)$ & $\mathrm{C} 3-\mathrm{H} 3$ & 0.9500 \\
\hline $\mathrm{O} 13-\mathrm{H} 13$ & $0.85(4)$ & $\mathrm{C} 5-\mathrm{H} 5$ & 0.9500 \\
\hline $\mathrm{N} 4-\mathrm{C} 4$ & $1.462(5)$ & $\mathrm{C} 6-\mathrm{H} 6$ & 0.9500 \\
\hline $\mathrm{O} 11-\mathrm{As} 1-\mathrm{C} 1$ & $107.90(13)$ & $\mathrm{C} 4-\mathrm{N} 4-\mathrm{H} 42$ & $109(2)$ \\
\hline $\mathrm{O} 11-\mathrm{As} 1-\mathrm{O} 12$ & $115.70(12)$ & $\mathrm{C} 4-\mathrm{N} 4-\mathrm{H} 43$ & $113(2)$ \\
\hline $\mathrm{O} 11-\mathrm{As} 1-\mathrm{O} 13$ & $103.83(14)$ & As1-C1-C2 & $118.4(3)$ \\
\hline $\mathrm{O} 13-\mathrm{As} 1-\mathrm{C} 1$ & $100.98(16)$ & $\mathrm{As} 1-\mathrm{C} 1-\mathrm{C} 6$ & $120.7(3)$ \\
\hline $\mathrm{O} 12-\mathrm{As} 1-\mathrm{O} 13$ & $109.99(14)$ & $\mathrm{C} 2-\mathrm{C} 1-\mathrm{C} 6$ & $120.6(3)$ \\
\hline $\mathrm{O} 12-\mathrm{As} 1-\mathrm{C} 1$ & $116.69(15)$ & $\mathrm{C} 1-\mathrm{C} 2-\mathrm{C} 3$ & $119.9(4)$ \\
\hline $\mathrm{Cl} 1-\mathrm{Cu} 1-\mathrm{Cl} 2$ & $89.58(4)$ & $\mathrm{C} 2-\mathrm{C} 3-\mathrm{C} 4$ & $119.4(4)$ \\
\hline $\mathrm{Cl} 2-\mathrm{Cu} 1-\mathrm{Cl} 2^{\mathrm{i}}$ & 180.00 & $\mathrm{~N} 4-\mathrm{C} 4-\mathrm{C} 3$ & $119.7(3)$ \\
\hline $\mathrm{Cl} 2-\mathrm{Cu} 1-\mathrm{Cl} 2^{\mathrm{ii}}$ & 86.07 (3) & $\mathrm{N} 4-\mathrm{C} 4-\mathrm{C} 5$ & $119.0(3)$ \\
\hline $\mathrm{Cl} 11^{\mathrm{i}}-\mathrm{Cu} 1-\mathrm{Cl} 2^{\mathrm{iii}}$ & $92.40(3)$ & $\mathrm{C} 3-\mathrm{C} 4-\mathrm{C} 5$ & $121.2(4)$ \\
\hline $\mathrm{C} 12^{\mathrm{i}}-\mathrm{Cu} 1-\mathrm{Cl} 2^{\mathrm{ii}}$ & $93.93(3)$ & $\mathrm{C} 4-\mathrm{C} 5-\mathrm{C} 6$ & $119.2(4)$ \\
\hline $\mathrm{Cl} 1-\mathrm{Cu} 1-\mathrm{Cl} 2^{\mathrm{i}}$ & $90.42(4)$ & $\mathrm{C} 1-\mathrm{C} 6-\mathrm{C} 5$ & $119.6(4)$ \\
\hline $\mathrm{Cl} 1-\mathrm{Cu} 1-\mathrm{Cl} 2^{\mathrm{iii}}$ & $87.60(3)$ & $\mathrm{C} 1-\mathrm{C} 2-\mathrm{H} 2$ & 120.00 \\
\hline $\mathrm{Cl} 1-\mathrm{Cu} 1-\mathrm{Cl1}^{\mathrm{i}}$ & 180.00 & $\mathrm{C} 3-\mathrm{C} 2-\mathrm{H} 2$ & 120.00 \\
\hline $\mathrm{Cu} 1-\mathrm{Cl} 2-\mathrm{Cu} 1^{\mathrm{iv}}$ & $162.25(5)$ & $\mathrm{C} 2-\mathrm{C} 3-\mathrm{H} 3$ & 120.00 \\
\hline As1-O11-H11 & $113(3)$ & $\mathrm{C} 4-\mathrm{C} 3-\mathrm{H} 3$ & 120.00 \\
\hline As1-O13-H13 & $112(3)$ & $\mathrm{C} 4-\mathrm{C} 5-\mathrm{H} 5$ & 120.00 \\
\hline $\mathrm{H} 42-\mathrm{N} 4-\mathrm{H} 43$ & $112(3)$ & $\mathrm{C} 6-\mathrm{C} 5-\mathrm{H} 5$ & 120.00 \\
\hline $\mathrm{H} 41-\mathrm{N} 4-\mathrm{H} 42$ & $105(4)$ & $\mathrm{C} 1-\mathrm{C} 6-\mathrm{H} 6$ & 120.00 \\
\hline $\mathrm{H} 41-\mathrm{N} 4-\mathrm{H} 43$ & $110(3)$ & $\mathrm{C} 5-\mathrm{C} 6-\mathrm{H} 6$ & 120.00 \\
\hline $\mathrm{C} 4-\mathrm{N} 4-\mathrm{H} 41$ & $108(3)$ & & \\
\hline $\mathrm{O} 11-\mathrm{As} 1-\mathrm{C} 1-\mathrm{C} 2$ & $28.1(4)$ & As $1-\mathrm{C} 1-\mathrm{C} 6-\mathrm{C} 5$ & $-170.7(3)$ \\
\hline $\mathrm{O} 11-\mathrm{As} 1-\mathrm{C} 1-\mathrm{C} 6$ & $-157.8(3)$ & $\mathrm{C} 2-\mathrm{C} 1-\mathrm{C} 6-\mathrm{C} 5$ & $3.2(6)$ \\
\hline $\mathrm{O} 12-\mathrm{As} 1-\mathrm{C} 1-\mathrm{C} 2$ & $160.4(3)$ & $\mathrm{C} 1-\mathrm{C} 2-\mathrm{C} 3-\mathrm{C} 4$ & $0.9(6)$ \\
\hline $\mathrm{O} 12-\mathrm{As} 1-\mathrm{C} 1-\mathrm{C} 6$ & $-25.6(4)$ & $\mathrm{C} 2-\mathrm{C} 3-\mathrm{C} 4-\mathrm{N} 4$ & $-175.7(4)$ \\
\hline $\mathrm{O} 13-\mathrm{As} 1-\mathrm{C} 1-\mathrm{C} 2$ & $-80.4(3)$ & $\mathrm{C} 2-\mathrm{C} 3-\mathrm{C} 4-\mathrm{C} 5$ & $2.0(6)$ \\
\hline $\mathrm{O} 13-\mathrm{As} 1-\mathrm{C} 1-\mathrm{C} 6$ & $93.6(3)$ & $\mathrm{N} 4-\mathrm{C} 4-\mathrm{C} 5-\mathrm{C} 6$ & $175.5(4)$ \\
\hline
\end{tabular}




\begin{tabular}{llll}
$\mathrm{As} 1-\mathrm{C} 1-\mathrm{C} 2-\mathrm{C} 3$ & $170.5(3)$ & $\mathrm{C} 3-\mathrm{C} 4-\mathrm{C} 5-\mathrm{C} 6$ & $-2.3(6)$ \\
$\mathrm{C} 6-\mathrm{C} 1-\mathrm{C} 2-\mathrm{C} 3$ & $-3.5(6)$ & $\mathrm{C} 4-\mathrm{C} 5-\mathrm{C} 6-\mathrm{C} 1$ & $-0.3(6)$ \\
\hline
\end{tabular}

Symmetry codes: (i) $-x+1,-y+1,-z+1$; (ii) $-x+3 / 2, y-1 / 2, z$; (iii) $x-1 / 2,-y+3 / 2,-z+1$; (iv) $x+1 / 2,-y+3 / 2,-z+1$.

Hydrogen-bond geometry $\left(\AA,{ }^{\circ}\right)$

\begin{tabular}{lllll}
\hline$D-\mathrm{H} \cdots A$ & $D-\mathrm{H}$ & $\mathrm{H} \cdots A$ & $D \cdots A$ & $D-\mathrm{H} \cdots A$ \\
\hline $\mathrm{O} 11-\mathrm{H} 11 \cdots \mathrm{O} 12^{\mathrm{v}}$ & $0.84(4)$ & $1.78(4)$ & $2.609(4)$ & $170(3)$ \\
$\mathrm{O} 13-\mathrm{H} 13 \cdots \mathrm{O} 12^{\text {vi }}$ & $0.85(4)$ & $1.79(4)$ & $2.610(4)$ & $162(4)$ \\
$\mathrm{N} 4-\mathrm{H} 41 \cdots \mathrm{C} 11^{\mathrm{ii}}$ & $0.88(2)$ & $2.38(2)$ & $3.235(4)$ & $163(4)$ \\
$\mathrm{N} 4-\mathrm{H} 42 \cdots \mathrm{C} 2^{\mathrm{iv}}$ & $0.87(4)$ & $2.47(4)$ & $3.301(4)$ & $161(3)$ \\
$\mathrm{N} 4-\mathrm{H} 43 \cdots \mathrm{C} 11$ & $0.89(3)$ & $2.39(2)$ & $3.208(4)$ & $153(3)$ \\
$\mathrm{C} 6-\mathrm{H} 6 \cdots \mathrm{O} 13^{\mathrm{ii}}$ & 0.95 & 2.40 & $3.268(5)$ & 152 \\
\hline
\end{tabular}

Symmetry codes: (ii) $-x+3 / 2, y-1 / 2, z$; (iv) $x+1 / 2,-y+3 / 2,-z+1$; (v) $x+1 / 2, y,-z+1 / 2$; (vi) $-x+2, y+1 / 2,-z+1 / 2$.

(IV) Poly[bis(4-arsonoanilinium) [tetra- $\mu$-chlorido-cadmate(II)]]

\section{Crystal data}

$\left(\mathrm{C}_{6} \mathrm{H}_{9} \mathrm{AsNO}_{3}\right)_{2}\left[\mathrm{CdCl}_{4}\right]$

$M_{r}=690.32$

Orthorhombic, $\mathrm{Pbca}$

Hall symbol: -P 2ac $2 \mathrm{ab}$

$a=7.5525(4) \AA$

$b=7.2578(3) \AA$

$c=38.5872(17) \AA$

$V=2115.14(17) \AA^{3}$

$Z=4$

\section{Data collection}

Oxford Diffraction Gemini-S CCD-detector diffractometer

Radiation source: ENHANCE (Mo) X-ray source

Graphite monochromator

Detector resolution: 16.077 pixels $\mathrm{mm}^{-1}$

$\omega$ scans

Absorption correction: multi-scan

(CrysAlis PRO; Rigaku OD, 2015

\section{Refinement}

Refinement on $F^{2}$

Least-squares matrix: full

$R\left[F^{2}>2 \sigma\left(F^{2}\right)\right]=0.032$

$w R\left(F^{2}\right)=0.070$

$S=1.11$

2070 reflections

139 parameters

5 restraints

Primary atom site location: structure-invariant direct methods

$$
F(000)=1336
$$

$D_{\mathrm{x}}=2.168 \mathrm{Mg} \mathrm{m}^{-3}$

Mo $K \alpha$ radiation, $\lambda=0.71073 \AA$

Cell parameters from 1959 reflections

$\theta=3.9-28.7^{\circ}$

$\mu=4.67 \mathrm{~mm}^{-1}$

$T=200 \mathrm{~K}$

Plate, colourless

$0.41 \times 0.25 \times 0.10 \mathrm{~mm}$

$T_{\min }=0.485, T_{\max }=0.980$

5452 measured reflections

2070 independent reflections

1778 reflections with $I>2 \sigma(I)$

$R_{\text {int }}=0.031$

$\theta_{\text {max }}=26.0^{\circ}, \theta_{\text {min }}=3.4^{\circ}$

$h=-9 \rightarrow 6$

$k=-8 \rightarrow 7$

$l=-44 \rightarrow 47$

Secondary atom site location: difference Fourier map

Hydrogen site location: inferred from neighbouring sites

$\mathrm{H}$ atoms treated by a mixture of independent and constrained refinement

$w=1 /\left[\sigma^{2}\left(F_{\mathrm{o}}{ }^{2}\right)+(0.0265 P)^{2}\right]$

where $P=\left(F_{\mathrm{o}}{ }^{2}+2 F_{\mathrm{c}}{ }^{2}\right) / 3$

$(\Delta / \sigma)_{\max }=0.001$

$\Delta \rho_{\max }=0.62 \mathrm{e} \AA^{-3}$

$\Delta \rho_{\min }=-0.50 \mathrm{e} \AA^{-3}$ 


\section{Special details}

Geometry. Bond distances, angles etc. have been calculated using the rounded fractional coordinates. All su's are estimated from the variances of the (full) variance-covariance matrix. The cell esds are taken into account in the estimation of distances, angles and torsion angles

Refinement. Refinement of $\mathrm{F}^{2}$ against ALL reflections. The weighted R-factor $\mathrm{wR}$ and goodness of fit $\mathrm{S}$ are based on $\mathrm{F}^{2}$, conventional R-factors $R$ are based on $F$, with $F$ set to zero for negative $F^{2}$. The threshold expression of $F^{2}>2 \operatorname{sigma}\left(\mathrm{F}^{2}\right)$ is used only for calculating R-factors(gt) etc. and is not relevant to the choice of reflections for refinement. R-factors based on $\mathrm{F}^{2}$ are statistically about twice as large as those based on F, and R- factors based on ALL data will be even larger.

Fractional atomic coordinates and isotropic or equivalent isotropic displacement parameters $\left(\AA^{2}\right)$

\begin{tabular}{lllll}
\hline & $x$ & $y$ & $z$ & $U_{\text {iso }} * U_{\text {eq }}$ \\
\hline Cd1 & 0.50000 & 0.50000 & 0.50000 & $0.0145(1)$ \\
C11 & $0.55662(14)$ & $0.52125(14)$ & $0.43568(3)$ & $0.0211(3)$ \\
C12 & $0.70634(14)$ & $0.79615(13)$ & $0.50986(3)$ & $0.0194(3)$ \\
As1 & $1.05703(6)$ & $0.75535(6)$ & $0.29043(1)$ & $0.0155(1)$ \\
O11 & $1.2690(4)$ & $0.8254(4)$ & $0.28422(7)$ & $0.0237(10)$ \\
O12 & $0.9688(4)$ & $0.6397(4)$ & $0.25798(7)$ & $0.0222(9)$ \\
O13 & $0.9450(4)$ & $0.9568(4)$ & $0.29732(8)$ & $0.0251(10)$ \\
N4 & $0.9693(5)$ & $0.4583(5)$ & $0.43687(9)$ & $0.0203(11)$ \\
C1 & $1.0425(6)$ & $0.6420(6)$ & $0.33478(9)$ & $0.0161(11)$ \\
C2 & $1.1509(6)$ & $0.7069(6)$ & $0.36094(10)$ & $0.0227(14)$ \\
C3 & $1.1299(6)$ & $0.6438(6)$ & $0.39430(10)$ & $0.0213(12)$ \\
C4 & $1.0021(5)$ & $0.5170(5)$ & $0.40065(10)$ & $0.0160(12)$ \\
C5 & $0.8963(6)$ & $0.4450(6)$ & $0.37506(11)$ & $0.0253(16)$ \\
C6 & $0.9169(6)$ & $0.5087(6)$ & $0.34161(10)$ & $0.0233(14)$ \\
H2 & 1.24010 & 0.79520 & 0.35590 & $0.0270^{*}$ \\
H3 & 1.20330 & 0.68800 & 0.41250 & $0.0260^{*}$ \\
H5 & 0.81070 & 0.35320 & 0.38030 & $0.0310^{*}$ \\
H6 & 0.84530 & 0.46130 & 0.32340 & $0.0280^{*}$ \\
H11 & $1.331(6)$ & $0.758(5)$ & $0.2703(10)$ & $0.0360^{*}$ \\
H13 & $0.952(6)$ & $1.034(5)$ & $0.2798(9)$ & $0.0380^{*}$ \\
H41 & $0.974(6)$ & $0.337(3)$ & $0.4383(12)$ & $0.0240^{*}$ \\
H42 & $1.048(5)$ & $0.515(5)$ & $0.4508(10)$ & $0.0240^{*}$ \\
H43 & $0.858(3)$ & $0.492(5)$ & $0.4422(11)$ & $0.0240^{*}$ \\
& & & & \\
\hline
\end{tabular}

Atomic displacement parameters $\left(\AA^{2}\right)$

\begin{tabular}{lllllll}
\hline & $U^{11}$ & $U^{22}$ & $U^{33}$ & $U^{12}$ & $U^{13}$ & $U^{23}$ \\
\hline Cd1 & $0.0138(2)$ & $0.0150(2)$ & $0.0146(2)$ & $-0.0006(2)$ & $0.0006(2)$ & $0.0013(2)$ \\
C11 & $0.0220(6)$ & $0.0257(6)$ & $0.0155(5)$ & $0.0001(4)$ & $0.0018(4)$ & $-0.0001(4)$ \\
C12 & $0.0191(5)$ & $0.0182(5)$ & $0.0210(5)$ & $-0.0071(4)$ & $0.0016(4)$ & $-0.0006(4)$ \\
As1 & $0.0148(2)$ & $0.0205(2)$ & $0.0112(2)$ & $0.0011(2)$ & $0.0003(2)$ & $0.0006(2)$ \\
O11 & $0.0169(17)$ & $0.0326(18)$ & $0.0215(15)$ & $-0.0013(14)$ & $0.0061(13)$ & $-0.0052(14)$ \\
O12 & $0.0217(17)$ & $0.0261(16)$ & $0.0187(15)$ & $0.0003(14)$ & $-0.0056(13)$ & $-0.0027(13)$ \\
O13 & $0.0287(19)$ & $0.0232(17)$ & $0.0233(16)$ & $0.0094(14)$ & $0.0066(15)$ & $0.0043(13)$ \\
N4 & $0.019(2)$ & $0.027(2)$ & $0.0149(18)$ & $0.0003(17)$ & $0.0016(16)$ & $0.0017(16)$ \\
C1 & $0.020(2)$ & $0.017(2)$ & $0.0113(19)$ & $0.0024(18)$ & $-0.0014(17)$ & $0.0020(16)$
\end{tabular}




\begin{tabular}{lllllll} 
C2 & $0.024(3)$ & $0.027(2)$ & $0.017(2)$ & $-0.011(2)$ & $-0.0014(19)$ & $0.0017(18)$ \\
C3 & $0.025(2)$ & $0.025(2)$ & $0.014(2)$ & $-0.006(2)$ & $-0.0034(18)$ & $0.0014(18)$ \\
C4 & $0.016(2)$ & $0.015(2)$ & $0.017(2)$ & $0.0051(17)$ & $0.0032(18)$ & $-0.0002(16)$ \\
C5 & $0.021(3)$ & $0.033(3)$ & $0.022(2)$ & $-0.014(2)$ & $0.001(2)$ & $0.002(2)$ \\
C6 & $0.021(2)$ & $0.034(3)$ & $0.015(2)$ & $-0.007(2)$ & $-0.0064(19)$ & $-0.0040(19)$ \\
\hline
\end{tabular}

Geometric parameters $\left(\AA,{ }^{\circ}\right)$

\begin{tabular}{|c|c|c|c|}
\hline $\mathrm{Cd} 1-\mathrm{Cl} 2^{\mathrm{i}}$ & $2.6820(10)$ & $\mathrm{N} 4-\mathrm{H} 41$ & $0.88(2)$ \\
\hline $\mathrm{Cd} 1-\mathrm{Cl} 2^{\mathrm{ii}}$ & $2.6931(10)$ & $\mathrm{N} 4-\mathrm{H} 42$ & $0.90(4)$ \\
\hline $\mathrm{Cd} 1-\mathrm{Cl1}^{\mathrm{i}}$ & $2.5232(12)$ & $\mathrm{N} 4-\mathrm{H} 43$ & $0.90(3)$ \\
\hline $\mathrm{Cd} 1-\mathrm{Cl} 1$ & $2.5232(12)$ & $\mathrm{C} 1-\mathrm{C} 2$ & $1.382(6)$ \\
\hline $\mathrm{Cd} 1-\mathrm{Cl} 2$ & $2.6820(10)$ & $\mathrm{C} 1-\mathrm{C} 6$ & $1.380(6)$ \\
\hline $\mathrm{Cd} 1-\mathrm{Cl} 2^{\mathrm{iii}}$ & $2.6931(10)$ & $\mathrm{C} 2-\mathrm{C} 3$ & $1.376(6)$ \\
\hline As1-O11 & $1.697(3)$ & $\mathrm{C} 3-\mathrm{C} 4$ & $1.356(6)$ \\
\hline As1-O12 & $1.648(3)$ & $\mathrm{C} 4-\mathrm{C} 5$ & $1.374(6)$ \\
\hline As1-O13 & $1.710(3)$ & $\mathrm{C} 5-\mathrm{C} 6$ & $1.380(6)$ \\
\hline As $1-\mathrm{C} 1$ & $1.902(4)$ & $\mathrm{C} 2-\mathrm{H} 2$ & 0.9500 \\
\hline $\mathrm{O} 11-\mathrm{H} 11$ & $0.86(4)$ & $\mathrm{C} 3-\mathrm{H} 3$ & 0.9500 \\
\hline $\mathrm{O} 13-\mathrm{H} 13$ & $0.88(4)$ & $\mathrm{C} 5-\mathrm{H} 5$ & 0.9500 \\
\hline $\mathrm{N} 4-\mathrm{C} 4$ & $1.482(5)$ & $\mathrm{C} 6-\mathrm{H} 6$ & 0.9500 \\
\hline $\mathrm{Cl} 1-\mathrm{Cd} 1-\mathrm{Cl} 2$ & $89.55(3)$ & $\mathrm{C} 4-\mathrm{N} 4-\mathrm{H} 41$ & $110(3)$ \\
\hline $\mathrm{Cl} 1-\mathrm{Cd} 1-\mathrm{Cl} 2^{\mathrm{iii}}$ & $88.11(3)$ & $\mathrm{C} 4-\mathrm{N} 4-\mathrm{H} 42$ & $109(2)$ \\
\hline $\mathrm{C} 11-\mathrm{Cd} 1-\mathrm{C} 11^{\mathrm{i}}$ & 180.00 & $\mathrm{C} 4-\mathrm{N} 4-\mathrm{H} 43$ & $107(3)$ \\
\hline $\mathrm{C} 11-\mathrm{Cd} 1-\mathrm{Cl} 2^{\mathrm{i}}$ & $90.45(3)$ & As $1-\mathrm{C} 1-\mathrm{C} 2$ & $118.4(3)$ \\
\hline $\mathrm{Cl} 1-\mathrm{Cd} 1-\mathrm{Cl} 2^{\mathrm{ii}}$ & $91.89(3)$ & $\mathrm{As} 1-\mathrm{C} 1-\mathrm{C} 6$ & $121.0(3)$ \\
\hline $\mathrm{Cl} 2-\mathrm{Cd} 1-\mathrm{Cl} 2^{\mathrm{iii}}$ & $93.34(3)$ & $\mathrm{C} 2-\mathrm{C} 1-\mathrm{C} 6$ & $120.4(4)$ \\
\hline $\mathrm{C} 11^{\mathrm{i}}-\mathrm{Cd} 1-\mathrm{C} 12$ & $90.45(3)$ & $\mathrm{C} 1-\mathrm{C} 2-\mathrm{C} 3$ & $120.1(4)$ \\
\hline $\mathrm{Cl} 2-\mathrm{Cd} 1-\mathrm{Cl} 2^{\mathrm{i}}$ & 180.00 & $\mathrm{C} 2-\mathrm{C} 3-\mathrm{C} 4$ & $118.5(4)$ \\
\hline $\mathrm{Cl} 2-\mathrm{Cd} 1-\mathrm{Cl} 2^{\mathrm{ii}}$ & $86.66(3)$ & $\mathrm{N} 4-\mathrm{C} 4-\mathrm{C} 3$ & $119.0(3)$ \\
\hline $\mathrm{O} 11-\mathrm{As} 1-\mathrm{C} 1$ & $108.13(17)$ & $\mathrm{N} 4-\mathrm{C} 4-\mathrm{C} 5$ & $118.1(3)$ \\
\hline $\mathrm{O} 11-\mathrm{As} 1-\mathrm{O} 12$ & $115.27(14)$ & $\mathrm{C} 3-\mathrm{C} 4-\mathrm{C} 5$ & $122.9(4)$ \\
\hline $\mathrm{O} 11-\mathrm{As} 1-\mathrm{O} 13$ & $103.45(14)$ & $\mathrm{C} 4-\mathrm{C} 5-\mathrm{C} 6$ & $118.7(4)$ \\
\hline $\mathrm{O} 13-\mathrm{As} 1-\mathrm{C} 1$ & $101.62(17)$ & $\mathrm{C} 1-\mathrm{C} 6-\mathrm{C} 5$ & $119.4(4)$ \\
\hline $\mathrm{O} 12-\mathrm{As} 1-\mathrm{O} 13$ & $110.70(15)$ & $\mathrm{C} 1-\mathrm{C} 2-\mathrm{H} 2$ & 120.00 \\
\hline $\mathrm{O} 12-\mathrm{As} 1-\mathrm{C} 1$ & $116.10(16)$ & $\mathrm{C} 3-\mathrm{C} 2-\mathrm{H} 2$ & 120.00 \\
\hline $\mathrm{Cd} 1-\mathrm{Cl} 2-\mathrm{Cd} 1^{\mathrm{iv}}$ & $154.00(4)$ & $\mathrm{C} 2-\mathrm{C} 3-\mathrm{H} 3$ & 121.00 \\
\hline As1-O11-H11 & $115(3)$ & $\mathrm{C} 4-\mathrm{C} 3-\mathrm{H} 3$ & 121.00 \\
\hline As1-O13-H13 & $113(3)$ & $\mathrm{C} 4-\mathrm{C} 5-\mathrm{H} 5$ & 121.00 \\
\hline $\mathrm{H} 42-\mathrm{N} 4-\mathrm{H} 43$ & $111(3)$ & $\mathrm{C} 6-\mathrm{C} 5-\mathrm{H} 5$ & 121.00 \\
\hline $\mathrm{H} 41-\mathrm{N} 4-\mathrm{H} 42$ & $113(4)$ & $\mathrm{C} 1-\mathrm{C} 6-\mathrm{H} 6$ & 120.00 \\
\hline $\mathrm{H} 41-\mathrm{N} 4-\mathrm{H} 43$ & $107(4)$ & $\mathrm{C} 5-\mathrm{C} 6-\mathrm{H} 6$ & 120.00 \\
\hline $\mathrm{C} 11-\mathrm{Cd} 1-\mathrm{Cl} 2-\mathrm{Cd} 1^{\mathrm{iv}}$ & $-45.92(10)$ & $\mathrm{As} 1-\mathrm{C} 1-\mathrm{C} 6-\mathrm{C} 5$ & $-172.4(3)$ \\
\hline $\mathrm{O} 11-\mathrm{As} 1-\mathrm{C} 1-\mathrm{C} 2$ & $32.4(4)$ & $\mathrm{C} 2-\mathrm{C} 1-\mathrm{C} 6-\mathrm{C} 5$ & $2.2(7)$ \\
\hline $\mathrm{O} 11-\mathrm{As} 1-\mathrm{C} 1-\mathrm{C} 6$ & $-152.9(3)$ & $\mathrm{C} 1-\mathrm{C} 2-\mathrm{C} 3-\mathrm{C} 4$ & $0.4(7)$ \\
\hline $\mathrm{O} 12-\mathrm{As} 1-\mathrm{C} 1-\mathrm{C} 2$ & $163.8(3)$ & $\mathrm{C} 2-\mathrm{C} 3-\mathrm{C} 4-\mathrm{N} 4$ & $-175.5(4)$ \\
\hline
\end{tabular}




$\begin{array}{llll}\mathrm{O} 12-\mathrm{As} 1-\mathrm{C} 1-\mathrm{C} 6 & -21.6(4) & \mathrm{C} 2-\mathrm{C} 3-\mathrm{C} 4-\mathrm{C} 5 & 2.0(6) \\ \mathrm{O} 13-\mathrm{As} 1-\mathrm{C} 1-\mathrm{C} 2 & -76.1(4) & \mathrm{N} 4-\mathrm{C} 4-\mathrm{C} 5-\mathrm{C} 6 & 175.3(4) \\ \mathrm{O} 13-\mathrm{As} 1-\mathrm{C} 1-\mathrm{C} 6 & 98.6(4) & \mathrm{C} 3-\mathrm{C} 4-\mathrm{C} 5-\mathrm{C} 6 & -2.2(6) \\ \mathrm{As} 1-\mathrm{C} 1-\mathrm{C} 2-\mathrm{C} 3 & 172.3(3) & \mathrm{C} 4-\mathrm{C} 5-\mathrm{C} 6-\mathrm{C} 1 & 0.1(6) \\ \mathrm{C} 6-\mathrm{C} 1-\mathrm{C} 2-\mathrm{C} 3 & -2.4(7) & & \end{array}$

Symmetry codes: (i) $-x+1,-y+1,-z+1$; (ii) $-x+3 / 2, y-1 / 2, z$; (iii) $x-1 / 2,-y+3 / 2,-z+1$; (iv) $x+1 / 2,-y+3 / 2,-z+1$.

Hydrogen-bond geometry $\left(\AA,{ }^{\circ}\right)$

\begin{tabular}{lllll}
\hline$D-\mathrm{H} \cdots A$ & $D-\mathrm{H}$ & $\mathrm{H} \cdots A$ & $D \cdots A$ & $D-\mathrm{H} \cdots A$ \\
\hline $\mathrm{O} 11-\mathrm{H} 11 \cdots \mathrm{O} 12^{\mathrm{v}}$ & $0.86(4)$ & $1.74(4)$ & $2.597(4)$ & $175(3)$ \\
$\mathrm{O} 13-\mathrm{H} 13 \cdots \mathrm{O} 12^{\text {vi }}$ & $0.88(4)$ & $1.75(4)$ & $2.596(4)$ & $160(4)$ \\
$\mathrm{N} 4-\mathrm{H} 41 \cdots \mathrm{Cl} 1^{\mathrm{ii}}$ & $0.88(2)$ & $2.31(2)$ & $3.178(4)$ & $170(5)$ \\
$\mathrm{N} 4-\mathrm{H} 42 \cdots \mathrm{C} 2^{\mathrm{iv}}$ & $0.90(4)$ & $2.37(4)$ & $3.257(4)$ & $168(3)$ \\
$\mathrm{N} 4-\mathrm{H} 43 \cdots \mathrm{C} 11$ & $0.90(3)$ & $2.30(2)$ & $3.150(4)$ & $158(4)$ \\
$\mathrm{C} 6-\mathrm{H} 6 \cdots \mathrm{O} 13^{\mathrm{ii}}$ & 0.95 & 2.41 & $3.246(5)$ & 146
\end{tabular}

Symmetry codes: (ii) $-x+3 / 2, y-1 / 2$, $z$; (iv) $x+1 / 2,-y+3 / 2,-z+1$; (v) $x+1 / 2, y,-z+1 / 2$; (vi) $-x+2, y+1 / 2,-z+1 / 2$. 